\title{
Uncovering Halide Mixing and Octahedral Dynamics in Vacancy-Or- dered Double Perovskites by Multinuclear Magnetic Resonance Spectroscopy
}

\author{
Abhoy Karmakar, Srija Mukhopadhyay, Pierre G.B. Gachod, Victor Arturo Mora-Gomez, Guy M. \\ Bernard, Alex Brown, and Vladimir K. Michaelis*
}

Department of Chemistry, University of Alberta, Edmonton, Alberta T6G 2G2, Canada

\begin{abstract}
Vacancy-ordered double perovskites $\mathrm{Cs}_{2} \mathrm{SnX}_{6}(\mathrm{X}=\mathrm{Cl}, \mathrm{Br}$, I) have emerged as promising lead-free and ambientstable materials for photovoltaic and optoelectronic applications. To advance these promising materials, it is crucial to determine the correlations between physical properties and their local structure and dynamics. Solid-state NMR spectroscopy of multiple NMR-active nuclei ${ }^{133} \mathrm{Cs},{ }^{119} \mathrm{Sn}$ and $\left.{ }^{35} \mathrm{Cl}\right)$ in these cesium $\operatorname{tin}(\mathrm{IV})$ halides has been used to decode the structure, which plays a key role in the materials' optical properties. The ${ }^{119} \mathrm{Sn}$ NMR chemical shifts span approximately $4000 \mathrm{ppm}$ and the ${ }^{119} \mathrm{Sn}$ spin-lattice relaxation times span three orders of magnitude when the halogen goes from chlorine to iodine in these diamagnetic compounds. Moreover, ultrawideline ${ }^{35} \mathrm{Cl}$ NMR spectroscopy for $\mathrm{Cs}_{2} \mathrm{SnCl}_{6}$ indicates an axially symmetric chlorine electric field gradient tensor with a large quadrupolar coupling constant of $c a .32 \mathrm{MHz}$, suggesting a chlorine that is directly attached to Sn(IV) ions. Variable temperature ${ }^{119} \mathrm{Sn}$ spin lattice relaxation time measurements uncover the presence of hidden dynamics of octahedral SnI 6 units in $\mathrm{Cs}_{2} \mathrm{SnI}_{6}$ with a low activation energy barrier of $12.45 \mathrm{~kJ} / \mathrm{mol}(0.129 \mathrm{eV})$. We further show that complete mixed-halide solid solutions of $\mathrm{Cs}_{2} \mathrm{SnCl}_{x} \mathrm{Br}_{6-x}$ and $\mathrm{Cs}_{2} \mathrm{SnBr}_{\mathrm{x}} \mathrm{I}_{6-\mathrm{x}}(0 \leq \mathrm{x} \leq 6)$ form at any halogen compositional ratio. ${ }^{119} \mathrm{Sn}$ and ${ }^{133} \mathrm{Cs} \mathrm{NMR}$ spectroscopy resolve the unique local $\mathrm{SnCl}_{n} \mathrm{Br}_{6-n}$ and $\mathrm{SnBr}_{n} \mathrm{I}_{6-n}(n=0-6)$ octahedral and $\mathrm{CsBr}_{m} \mathrm{I}_{12-m}$ $(m=0-12)$ cuboctahedral environments in the mixed-halide samples. The experimentally observed ${ }^{119} \mathrm{Sn}$ NMR results are consistent with magnetic shielding parameters obtained by density functional theory computations to verify random halogen distribution in mixed-halide analogues. Finally, we demonstrate the difference in the local structures and optical absorption properties of $\mathrm{Cs}_{2} \mathrm{SnI}_{6}$ samples prepared by solvent-assisted and solvent-free synthesis routes.
\end{abstract}

\section{INTRODUCTION}

Lead halide perovskites $\left(\mathrm{APbX}_{3} ; \mathrm{A}=\mathrm{Cs}^{+}, \mathrm{CH}_{3} \mathrm{NH}_{3}{ }^{+}\right.$, $\left.\mathrm{CH}\left(\mathrm{NH}_{2}\right)_{2}+\mathrm{X}=\mathrm{Cl}^{-}, \mathrm{Br}^{-}, \mathrm{I}^{-}\right)$have gained tremendous attention as semiconducting materials due to their desirable optical and electrical properties including in photovoltaic solar cells, ${ }^{1}$ light-emitting diodes, ${ }^{2}$ hard-radiation detectors, ${ }^{3}$ photocatalytic reactions ${ }^{4}$ and beyond. ${ }^{5,6}$ Although lead-containing perovskites have high power conversion efficiencies (PCE) of $25.5 \%$ in photovoltaic solar cells, ${ }^{7}$ they, unfortunately, suffer from mediocre chemical stability ${ }^{8-11}$ and the potential risk of lead toxicity. ${ }^{12,13}$ The tin(II) halide perovskites $\mathrm{ASnX}_{3}$ are possible alternatives with lower toxicity, but they exhibit lower PCE of up to $10 \%$ and rapidly oxidize in $\operatorname{air}\left(\mathrm{Sn}^{2+}\right.$ to $\left.\mathrm{Sn}^{4+}\right) \cdot{ }^{14-17}$

Vacancy-ordered double perovskites $\mathrm{A}_{2} \mathrm{BX}_{6}\left(\mathrm{~A}=\mathrm{Cs}^{+}\right.$, $\left.\mathrm{CH}_{3} \mathrm{NH}_{3}{ }^{+}, \mathrm{CH}\left(\mathrm{NH}_{2}\right)_{2}{ }_{2} ; \mathrm{B}=\mathrm{Sn}^{4+} ; \mathrm{X}=\mathrm{Cl}^{-}, \mathrm{Br}^{-}, \mathrm{I}^{-}\right)$are an alternative family of perovskites, demonstrating much higher ambient stability and lower toxicity. ${ }^{18}$ The structure of $\mathrm{A}_{2} \mathrm{BX}_{6}$ can be described as an $\mathrm{ABX}_{3}$ perovskite, with half of the $\mathrm{B}$ sites removed in an ordered fashion (Figure 1a). ${ }^{19}$ For example, $\mathrm{Cs}_{2} \mathrm{SnX}_{6}$ are cubic in structure with 12 halogens surrounding the $\mathrm{A}$-site to form a $\mathrm{CsX}_{12}$ cuboctahedron, whereas the B-site is octahedrally coordinated with six halogen anions to form $\mathrm{BX}_{6}$ octahedra (Figure 1a). The iodide analogue, $\mathrm{Cs}_{2} \mathrm{SnI}_{6}$, has a bandgap (1.25-1.62 eV) close to the optimum value $(1.34 \mathrm{eV})$ to maximize thin-film solar cell efficiency. ${ }^{18,20,21}$ Recently, $\mathrm{Cs}_{2} \mathrm{SnI}_{6}$ has shown promising optoelectronic properties to develop air-stable and lead-free perovskite photovoltaics. ${ }^{22}$ The mixed-halide analogues $\mathrm{Cs}_{2} \mathrm{SnBr}_{\mathrm{x}} \mathrm{I}_{6-\mathrm{x}}$ reveal bandgap tailorability with halogen composition, ${ }^{23}$ making them suitable as hole-transporting materials in solid-state dye-sensitized solar cells. ${ }^{24}$ On the other hand, $\mathrm{Cs}_{2} \mathrm{SnX}_{6}$ nanocrystals have demonstrated tunable light emission and photocatalytic activity. ${ }^{25-27}$ Recently, doped $\left(\mathrm{Bi}^{3+}\right.$ and $\left.\mathrm{Sb}^{3+}\right) \mathrm{Cs}_{2} \mathrm{SnCl}_{6}$ has been shown to produce efficient blue and orange-red light emission; this development brings about de novo opportunities for these materials as solid-state lighting candidates. ${ }^{28-30}$

To date, vacancy-ordered halide double perovskites have been extensively characterized by X-ray diffraction (XRD) techniques, which provide information about the average long-range structure, but not about the local chemical environments. Fundamentally, it is essential to correlate the bulk photophysical properties with the microstructural characteristics for perovskites. Solid-state nuclear magnetic 
resonance (NMR) spectroscopy is a robust analytical characterization tool to determine short- $(<5 \AA)$ and medium(5-10 $)$ range structures as well as ion dynamics in perovskites. ${ }^{16,31-47}$ More specifically, ${ }^{133} \mathrm{Cs}\left(I=7 / 2, Q_{\mathrm{m}}=-0.34 \mathrm{fm}^{2}\right.$, $100 \%$ abundance $)^{48}$ is an ideal NMR-active nucleus to identify the chemical environments around the A-site in perovskites. ${ }^{36,42,47,49-52}{ }^{119} \mathrm{Sn}(I=1 / 2,8.6 \%$ abundance), the most receptive nucleus among three NMR-active tin isotopes $\left({ }^{115} \mathrm{Sn},{ }^{117} \mathrm{Sn},{ }^{119} \mathrm{Sn}\right.$ ) (Table S1), ${ }^{48}$ has been used to resolve the local B-site structural environments and halogen dynamics in $\mathrm{ABX}_{3}$ perovskites and other tin-containing compounds. ${ }^{16,17,53-59}$ Furthermore, the ${ }^{119} \mathrm{Sn}$ NMR spectra displays an extensive range to diamagnetic Sn-containing compounds which has been recently extended to span nearly 6,000 ppm. ${ }^{16,60-62}$

This study shows an impressive ability to tailor the optical bandgap over a $3 \mathrm{eV}$ range using a high energy mechanochemical synthetic design of vacancy ordered double perovskite $\mathrm{Cs}_{2} \mathrm{SnCl}_{x} \mathrm{Br}_{6-x}$ and $\mathrm{Cs}_{2} \mathrm{SnBr}_{x} \mathrm{I}_{6-\mathrm{x}}$ mixed-halide materials. Powder XRD and NMR spectroscopy allow identification of the long-, medium- and short-range chemical and coordination environments around Cs and Sn sites upon interhalogen substitutions in mixed-halide analogues. The experimentally observed broad (>100 kHz) and multiple resonances in the ${ }^{119} \mathrm{Sn}$ NMR spectra for the mixed-halide analogues are correlated with ${ }^{119} \mathrm{Sn}$ magnetic shielding parameters obtained from density functional theory (DFT) computations and reveal the importance of the spin-orbit shielding term. Variable temperature ${ }^{119} \mathrm{Sn}$ NMR captures the activation energy of the rapid $\mathrm{SnI}_{6}$ octahedral dynamics in $\mathrm{Cs}_{2} \mathrm{SnI}_{6}$. Finally, $\mathrm{Cs}_{2} \mathrm{SnI}_{6}$ materials prepared by solvent-assisted or solvent-free synthesis routes are discussed to uncover the influences of solvent- vs. solvent-free synthesis on the local chemical structure and bulk optical properties. The comparison is important as mechanochemistry continues to be shown as an effective greener approach for synthesizing solids. (a)
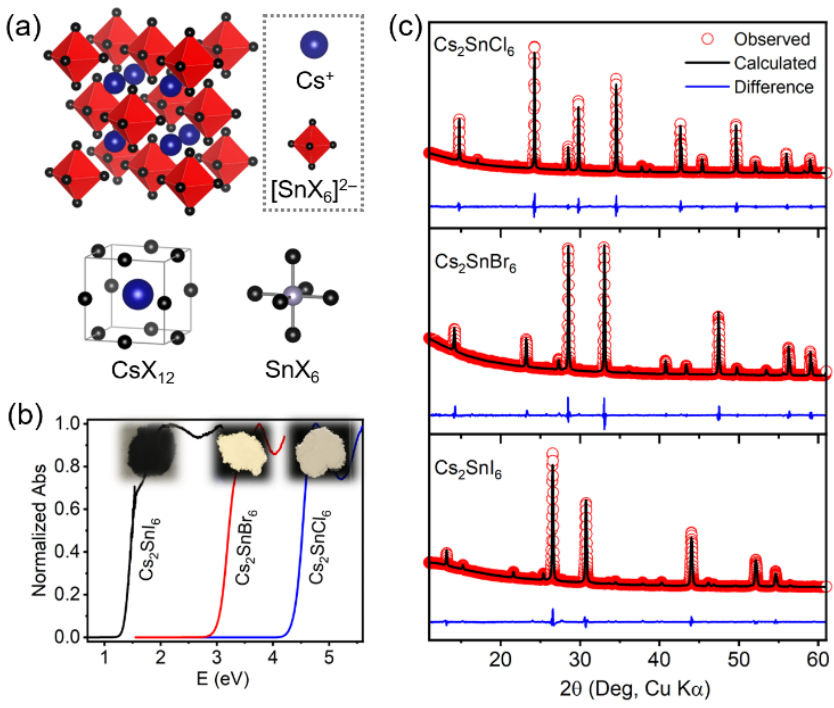

Figure 1. (a) Crystal structure of $\mathrm{Cs}_{2} \mathrm{SnX}_{6}$, local $\mathrm{CsX}_{12}$ cuboctahedral environment of 12 halides around cesium, and local $\mathrm{SnX}_{6}$ octahedral environment of six halides around tin. (b) Optical absorption spectra (inset - photographs) and (c) Powder XRD patterns of solvent synthesized $\mathrm{Cs}_{2} \mathrm{SnX}_{6}$ parents.

Table 1. Unit cell parameters, direct bandgap, solid-state ${ }^{133} \mathrm{Cs}$ and ${ }^{119} \mathrm{Sn}$ NMR results $\left(v_{\mathrm{r}}=13 \mathrm{kHz}, \mathrm{B}_{0}=11.75 \mathrm{~T}\right)$ for solvent synthesized $\mathrm{Cs}_{2} \mathrm{SnX}_{6}$ parents.

\begin{tabular}{|c|c|c|c|c|c|c|c|}
\hline \multirow[t]{2}{*}{ Samples } & \multirow{2}{*}{$\begin{array}{c}\text { Cell parameter } \\
(\AA)\end{array}$} & \multirow{2}{*}{$\begin{array}{c}\text { Bandgap } \\
(\mathrm{eV})\end{array}$} & \multicolumn{2}{|c|}{ 133Cs NMR } & \multicolumn{3}{|c|}{${ }^{119}$ Sn NMR } \\
\hline & & & $\delta(\mathrm{ppm})$ & fwhm (Hz) & $\delta($ ppm $)$ & fwhm $(\mathrm{kHz})$ & $T_{1}(\mathrm{~s})$ \\
\hline $\mathrm{Cs}_{2} \mathrm{SnCl}_{6}$ & $10.3826(1)$ & 4.48 & $125.8 \pm 0.1$ & $62 \pm 2$ & $-708 \pm 1$ & $1.5 \pm 0.1$ & $146 \pm 6$ \\
\hline $\mathrm{Cs}_{2} \mathrm{SnBr}_{6}$ & $10.8377(2)$ & 3.13 & $112.3 \pm 0.2$ & $175 \pm 5$ & $-1964 \pm 2$ & $5.2 \pm 0.2$ & $5.4 \pm 0.2$ \\
\hline $\mathrm{Cs}_{2} \mathrm{Snn}_{6}$ & $11.6342(2)$ & 1.42 & $-46.1 \pm 0.1$ & $66 \pm 2$ & $-4540 \pm 5$ & $11.5 \pm 0.5$ & $0.170 \pm 0.007$ \\
\hline
\end{tabular}

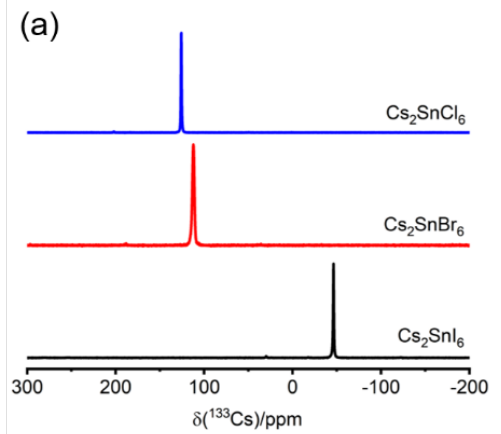

(b)

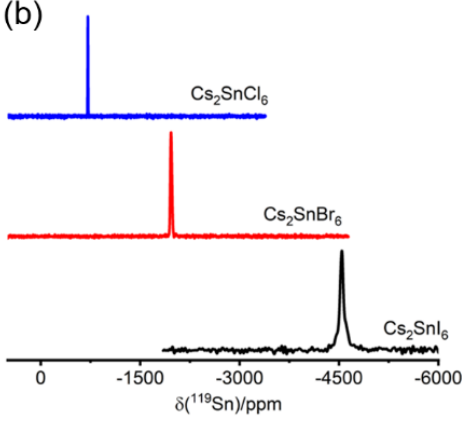

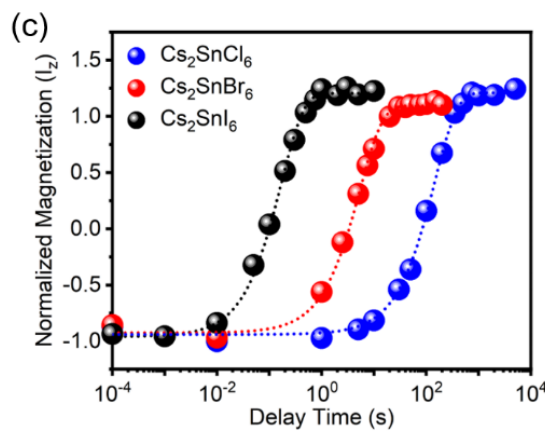


Figure 2. Solid-state (a) ${ }^{133} \mathrm{Cs}$, (b) ${ }^{119} \mathrm{Sn}$ NMR spectra and (c) inversion recovery plot to measure ${ }^{119} \mathrm{Sn}$ spin-lattice ( $T_{1}$ ) relaxation values for the solvent synthesized $\mathrm{Cs}_{2} \mathrm{SnX}_{6}$ parents. NMR experiments were performed at $11.75 \mathrm{~T}$ with magic-angle spinning frequency of $13 \mathrm{kHz}$.

\section{RESULTS AND DISCUSSION}

Solvent Synthesized $\mathrm{Cs}_{2} \mathrm{SnX}_{6}$ Parents. $\mathrm{Cs}_{2} \mathrm{SnX}_{6}\left(\mathrm{X}=\mathrm{Cl}^{-}, \mathrm{Br}^{-}\right.$, $\left.\mathrm{I}^{-}\right)$parents were prepared by solvent-assisted synthetic routes starting with $\mathrm{CsX}$ and $\mathrm{SnX}_{4}$ precursors (see SI). As determined by energy-dispersive X-ray spectroscopy (EDS), the chemical compositions agree well with the expected $\mathrm{Cs}_{2} \mathrm{SnX}_{6}$ chemical formulation formed by solvent synthesis (Table S2 and Figure S1). $\mathrm{Cs}_{2} \mathrm{SnX}_{6}$ samples are polycrystalline with micron-sized particles as determined by fieldemission scanning electron microscopy (FESEM) (Figure S2). The color of $\mathrm{Cs}_{2} \mathrm{SnX}_{6}$ changes from white $\left(\mathrm{Cs}_{2} \mathrm{SnCl}_{6}\right)$ to faint yellow $\left(\mathrm{Cs}_{2} \mathrm{SnBr}_{6}\right)$ to black $\left(\mathrm{Cs}_{2} \mathrm{SnI}_{6}\right)$, consistent with a decrease in their optical absorption edge (Figure 1b). The powder XRD patterns are consistent with a cubic structure $\left(\mathrm{K}_{2} \mathrm{PtCl}_{6}\right.$-type, space group $F m \overline{3} m$ ) for all three $\mathrm{Cs}_{2} \mathrm{SnX}_{6}$ parents at room temperature (Figure $1 \mathrm{c}$ ). The cell parameters, as refined by Le Bail fitting of the powder XRD patterns, systematically increase for the $\mathrm{Cs}_{2} \mathrm{SnX}_{6}$ parents as the ionic radius of the associated halogen anion increases from $1.81 \AA$ $\mathrm{r}\left(\mathrm{Cl}^{-}\right)<1.96 \AA \mathrm{r}\left(\mathrm{Br}^{-}\right)<2.20 \AA \mathrm{r}\left(\mathrm{I}^{-}\right)$(Table 1). ${ }^{63}$

The optical absorption spectra, which are extracted from the diffuse reflectance spectra by the Kubelka-Munk function, exhibit a gradual shift of the absorption edge to lower energy as $\mathrm{Cl}$ is replaced by $\mathrm{Br}$ and followed by $\mathrm{I}$ in $\mathrm{Cs}_{2} \mathrm{SnX}_{6}$ parents. Considering a direct bandgap property for these semiconducting materials, ${ }^{64}$ the optical bandgap values are extracted from the linear region in the Tauc plot of $(\alpha h v)^{2}$ against energy (Figure S3). The bandgap in $\mathrm{Cs}_{2} \mathrm{SnX}_{6}$ parents exhibits a dramatic decrease from $4.48 \mathrm{eV}$ for $\mathrm{Cs}_{2} \mathrm{SnCl}_{6}$ to $1.42 \mathrm{eV}$ for $\mathrm{Cs}_{2} \mathrm{SnI}_{6}$, spanning across $3 \mathrm{eV}$ (Table 1).

Solid-state ${ }^{133} \mathrm{Cs}$ and ${ }^{119} \mathrm{Sn}$ NMR spectroscopy was used to investigate the local halogen environments around cesium and tin. The Cs atoms occupy a crystallographic site with $\overline{4} 3 m$ symmetry in $\mathrm{Cs}_{2} \mathrm{SnX}_{6}$. Twelve nearest-neighboring halogen atoms surround them to form a local Cs $\mathrm{X}_{12}$ cuboctahedral environment (Figure 1a). Accordingly, the ${ }^{133} \mathrm{Cs}$ magicangle spinning (MAS) NMR spectra exhibit a single sharp resonance with chemical shifts of $125.8 \mathrm{ppm}$ (full width at half maximum, fwhm $=62 \mathrm{~Hz}$ ) for $\mathrm{Cs}_{2} \mathrm{SnCl}_{6}, 114.6 \mathrm{ppm}$ (fwhm $=175 \mathrm{~Hz}$ ) for $\mathrm{Cs}_{2} \mathrm{SnBr}_{6}$ and $-41.4 \mathrm{ppm}$ (fwhm = 66 $\mathrm{Hz}$ ) for $\mathrm{Cs}_{2} \mathrm{SnI}_{6}$, indicating one unique crystallographic Cs site (Figure $2 \mathrm{a}$ and Table 1 ). A gradual change in the ${ }^{133} \mathrm{Cs}$ NMR chemical shift towards lower frequency is in agreement with a recent observation on $\mathrm{CsSnX}_{3}$ perovskites, ${ }^{16}$ but in contrast to $\mathrm{CsPBX}_{3}$ perovskites, ${ }^{36}$ where an opposite trend in the chemical shift was observed. Due to Cs residing in the center of a perfect $\mathrm{CsX}_{12}$ cuboctahedral environment in $\mathrm{Cs}_{2} \mathrm{SnX}_{6}$ parents, a vanishing ${ }^{133} \mathrm{Cs}$ quadrupole coupling constant $\left(C_{Q}=0 \mathrm{kHz}\right)$ is expected with no spinning sidebands (SSBs) under MAS conditions. However, a low-intensity $(<1 \%)$ SSB was observed under slow MAS $\left(v_{\mathrm{r}}=5 \mathrm{kHz}\right)$ for all three $\mathrm{Cs}_{2} \mathrm{SnX}_{6}$ parents (Figure $\mathrm{S} 4$ ), which is associated to intrinsic defects such as halogen vacancies. ${ }^{49,65}$
The Sn atoms occupy $m \overline{3} m$ site symmetry in the $\mathrm{Cs}_{2} \mathrm{SnX}_{6}$ structure with six nearest-neighbor halogen atoms surrounding $\mathrm{Sn}$ to form local $\mathrm{SnX}_{6}$ octahedral units (Figure 1a). The $\mathrm{Cs}_{2} \mathrm{SnX}_{6}$ parents exhibit symmetric ${ }^{119} \mathrm{Sn}$ NMR resonances with no evidence of SSBs under MAS conditions (Figure $2 \mathrm{~b}$ ), consistent with the highly symmetric local $\mathrm{SnX}_{6}$ octahedral environment. The ${ }^{119} \mathrm{Sn}$ NMR spectra in $\mathrm{Cs}_{2} \mathrm{SnX}_{6}$ shift towards lower frequency with a chemical shift of -708 ppm for $\mathrm{Cs}_{2} \mathrm{SnCl}_{6},-1964 \mathrm{ppm}$ for $\mathrm{Cs}_{2} \mathrm{SnBr}_{6}$ and $-4540 \mathrm{ppm}$ for $\mathrm{Cs}_{2} \mathrm{SnI}_{6}$, a large change spanning over $3800 \mathrm{ppm}$ for diamagnetic tin-containing compounds. The trend of increased Sn shielding (to lower frequency) with increased halogen atomic number observed here, a normal halogen dependence (NHD), is opposite to previous studies on Sn(II)-based perovskites $\left(\mathrm{ASnX}_{3}\right)$, where an inverse halogen dependence (IHD) was observed with a smaller chemical shift range (< $1300 \mathrm{ppm}) .{ }^{16,56,66}$ The unprecedented change in ${ }^{119} \mathrm{Sn}$ chemical shift was further studied using theoretical calculations, which revealed that the diamagnetic and paramagnetic shielding terms are nearly unchanged. Hence, the changes in chemical shift originate from considerable spin-orbit effects whereby this term changes $c a .4500 \mathrm{ppm}$ as the halide anions increase in size (Table S3), emphasizing the need to consider relativistic and spin-orbit effects when performing DFT calculations for these materials which contain heavy elements. The ${ }^{119} \mathrm{Sn}$ NMR linewidths depend on the halogen in $\mathrm{Cs}_{2} \mathrm{SnX}_{6}$, increasing monotonically from $1.5\left(\mathrm{Cs}_{2} \mathrm{SnCl}_{6}\right)$ to 5.2 $\left(\mathrm{Cs}_{2} \mathrm{SnBr}_{6}\right)$ to $11.5 \mathrm{kHz}\left(\mathrm{Cs}_{2} \mathrm{SnI}_{6}\right)$. For $\mathrm{Cs}_{2} \mathrm{SnBr}_{6}$, the ${ }^{119} \mathrm{Sn}$ NMR linewidth and lineshape are independent of the magnetic field strength ( $B_{0}=7.05$ to $11.75 \mathrm{~T}$, Figure $\left.S 5\right)$, indicating no evidence of shielding anisotropy. Furthermore, the ${ }^{119}$ Sn NMR linewidth decreases slightly ( $c a .0 .8 \mathrm{kHz}$ ) once MAS is applied (Figure S6), confirming a small contribution from heteronuclear dipolar coupling (through space) between $\mathrm{Sn}$ and $\mathrm{Br}$ nuclei ${ }^{79 / 81} \mathrm{Br}: I=3 / 2$, total abundance $=$ $100 \%)$. These findings suggest that a dominant ${ }^{1} J\left({ }^{119} \mathrm{Sn}-{ }^{79 / 81} \mathrm{Br}\right)$ scalar coupling between ${ }^{119} \mathrm{Sn}$ and the six directly bonded ${ }^{79 / 81} \mathrm{Br}$ nuclei in $\mathrm{SnBr}_{6}$ octahedra is responsible for the ${ }^{119} \mathrm{Sn}$ NMR linewidth. ${ }^{35,36,38,67}$ The ${ }^{119} \mathrm{Sn}$ spin-lattice relaxation time $\left(T_{1}\right)$ decreases from $\mathrm{Cs}_{2} \mathrm{SnCl}_{6}\left(T_{1}=146\right.$ s) to $\mathrm{Cs}_{2} \mathrm{SnBr}_{6}\left(T_{1}=5.4 \mathrm{~s}\right)$ to $\mathrm{Cs}_{2} \mathrm{SnI}_{6}\left(T_{1}=0.170 \mathrm{~s}\right)$, a difference of three orders of magnitude (Figure 2c and Table 1), which is comparable to recent observation on $\mathrm{ASnX}_{3}$ perovskites. ${ }^{16,17}$ The trend in ${ }^{119} \mathrm{Sn} T_{1}$ values where the relaxation decreases dramatically with increasing halide atomic number (Figure 2c) follows the inverse of the trend in the scalar coupling strength where ${ }^{1} J\left({ }^{119} \mathrm{Sn}-{ }^{127} \mathrm{I}\right)>{ }^{1} J\left({ }^{119} \mathrm{Sn}-{ }^{79 / 81} \mathrm{Br}\right)>$ ${ }^{1} J\left({ }^{119} \mathrm{Sn}-{ }^{35 / 37} \mathrm{Cl}\right)$. Hence this interaction is thought to be the dominant relaxation mechanism and expected to be fastest for $\mathrm{Cs}_{2} \mathrm{SnI}_{6}$, intermediate for $\mathrm{Cs}_{2} \mathrm{SnBr}_{6}$ and slowest for $\mathrm{Cs}_{2} \mathrm{SnCl}_{6}$, as previously observed in other tin halide perovskite compounds. $16,68,69$

Chlorine-35 NMR spectroscopy in $\mathrm{Cs}_{2} \mathrm{SnCl}_{6}$. The stable halogen elements are NMR active, but unlike ${ }^{19} \mathrm{~F}(I=1 / 2)$, the heavier group 17 elements are quadrupolar (nuclear spin, $I$ 
$=3 / 2\left({ }^{35 / 37} \mathrm{Cl},{ }^{79 / 81} \mathrm{Br}\right)$ or $\left.I=5 / 2\left({ }^{127} \mathrm{I}\right)\right)$ with large quadrupole moments (Table S1). ${ }^{35} \mathrm{Cl}$ NMR spectroscopy has been used to investigate the local structural environments in pharmaceuticals, amino acids, lead halide perovskites, organic and organometallic compounds, due to its overall NMR sensitivity as well as the insight into structure that it provides. ${ }^{70-75}$ Crystallographically, the halogen atoms in $\mathrm{Cs}_{2} \mathrm{SnX}_{6}$ occupy a single site with symmetry $4 m . m$, where each halogen is bonded to a single Sn atom (Figure 1a). Hence, this lower site symmetry of the $\mathrm{X}$ site in $\mathrm{Cs}_{2} \mathrm{SnX}_{6}$ is expected to impart a sizable electric field gradient (EFG) that would cause substantial spectral broadening. Figure 3 shows the frequencystepped wide-band, uniform, and smooth truncation CarrPurcell-Meiboom-Gill (WURST-CPMG) ${ }^{76,77}{ }^{35} \mathrm{Cl}$ NMR spectrum of $\mathrm{Cs}_{2} \mathrm{SnCl}_{6}$. The ultrawideline NMR spectrum that spans ca. 2.7 MHz at $11.75 \mathrm{~T}$ was obtained in 12 steps using the variable offset cumulative spectra (VOCS) technique (Figure S7). Fitting the central transition reveals that $\delta_{\text {iso }}=$ $560 \pm 20 \mathrm{ppm}, C_{\mathrm{Q}}=32.0 \pm 0.3 \mathrm{MHz}$ and that the quadrupolar asymmetry parameter, $\eta=0.00$. The spectral lineshape is consistent with the presence of a terminal $\mathrm{Cl}$ atom in $\mathrm{Cs}_{2} \mathrm{SnCl}_{6}$, as the terminal $\mathrm{Cl}$ atoms are in a higher axial symmetric environment, which results in a large $C_{\mathrm{Q}}$ and a low $\eta$. Moreover, the large ${ }^{35} \mathrm{Cl} C_{Q}$ value confirms the chloride ions are coordinated to a Sn(IV) ion in a local $\mathrm{SnCl}_{6}$ octahedral environment. ${ }^{75}$ In contrast, $\mathrm{Cl}$ atoms attached to $\mathrm{Sn}$ (II) ions show lower $C_{\mathrm{Q}}$ values of $<30 \mathrm{MHz} .^{75}$ We note that bulk and nanocrystalline forms of $\mathrm{CsPbCl}_{3}$ perovskite exhibit lower ${ }^{35} \mathrm{Cl} C_{\mathrm{Q}}$ values of $c a .15 .5 \mathrm{MHz}(\eta=0) .{ }^{73}$

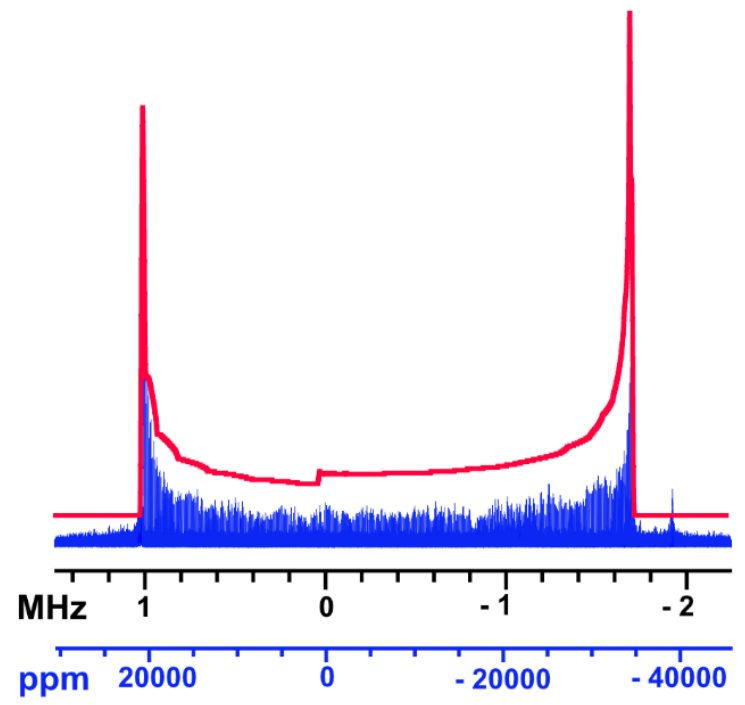

Figure 3. Experimental (lower trace, blue) and simulated (upper trace, red) ${ }^{35} \mathrm{Cl}$ WURST-CPMG solid-state NMR spectrum of $\mathrm{Cs}_{2} \mathrm{SnCl}_{6}$ parent $\left(v_{\mathrm{r}}=0 \mathrm{kHz}, \mathrm{B}_{0}=11.75 \mathrm{~T}\right.$, sum of 12 frequency steps, $250 \mathrm{kHz} / \mathrm{step})$.

SnI $_{6}$ Octahedral Dynamics in $\mathrm{Cs}_{2} \mathrm{SnI}_{6}$. Anharmonic lattice dynamics of $\mathrm{BX}_{6}$ octahedra in halide perovskites play a vital role in optical and electrical properties of these materials. ${ }^{78-}$ 80 The isolated $\mathrm{BX}_{6}$ octahedral units in $\mathrm{A}_{2} \mathrm{BX}_{6}$ vacancy-ordered double perovskites extend the degree of dynamical freedom compared to that for their sister materials, $\mathrm{ABX}_{3}$ perovskites (Figure 4a). Recently, X-ray pair distribution function analysis on $\mathrm{Cs}_{2} \mathrm{SnI}_{6}$ has revealed asymmetry in the interoctahedral I-I distance, which can be correlated with rotational disorder for the isolated SnI 6 octahedral units, but the technique does not provide information about the activation energy associated with this rotation. ${ }^{81,82}$ Therefore, variable-temperature ${ }^{119} \mathrm{Sn}$ NMR measurements were carried out on a solvent-synthesized $\mathrm{Cs}_{2} \mathrm{SnI}_{6}$ sample to probe specifically the anharmonicity of the isolated octahedral $\mathrm{SnI}_{6}$ units to determine the associated activation energies needed for this unique property.

As the sample temperature increases from 208 to $380 \mathrm{~K}$, the ${ }^{119} \mathrm{Sn}$ NMR resonance shifts linearly towards lower frequencies from -4522 to -4547 ppm (Table S4, Figures $4 \mathrm{~b}$ and S8), attributed to a change in the interatomic distance as the temperature changes. The linewidth of ${ }^{119} \mathrm{Sn}$ NMR resonance remains nearly unaltered (fwhm $=18 \pm 1 \mathrm{kHz}$ ) across the temperature ranges studied, indicating that the ${ }^{119} \mathrm{Sn}$ NMR linewidth in $\mathrm{Cs}_{2} \mathrm{SnI}_{6}$ is primarily driven by indirect (D) and direct (dipolar) spin-spin coupling between ${ }^{119} \mathrm{Sn}$ and ${ }^{127}$ I nuclei. Most interestingly, the ${ }^{119} \mathrm{Sn}$ NMR spin-lattice relaxation time $\left(T_{1}\right)$ changes drastically from $4.6 \mathrm{~s}(208 \mathrm{~K})$ to $0.12 \mathrm{~s}(380 \mathrm{~K})$; nearly a 40 -fold change in the $T_{1}$ over the $170 \mathrm{~K}$ temperature range. A plot of $\ln \left[T_{1} / \mathrm{s}\right]$ against $[1000 / \mathrm{T}(\mathrm{K})]$ is linear allowing a determination of an activation energy of $12.45 \pm 0.87 \mathrm{~kJ} / \mathrm{mol}(0.129 \pm 0.009 \mathrm{eV})$, in accordance with the Arrhenius relationship (see Table S4, Figure 4b, Supplementary Note 1), suggesting a low energy barrier for the $\mathrm{SnI}_{6}$ octahedral lattice dynamics. A comparable temperature dependent change in ${ }^{119} \mathrm{Sn} T_{1}$ has been reported for the ionic conductors, $\mathrm{CH}_{3} \mathrm{NH}_{3} \mathrm{SnBr}_{3}$ and $\mathrm{CsSnBr}$ perovskites, where much higher activation energies (0.3-0.4 eV) were observed for rapid halogen migration. ${ }^{16,17}$
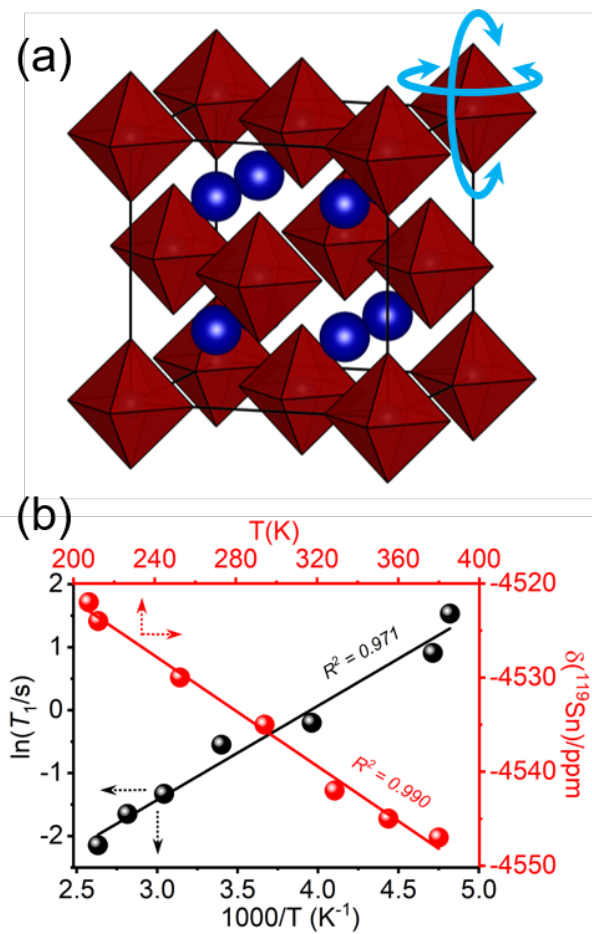

Figure 4. (a) Schematic diagram of $\mathrm{SnI}_{6}$ anharmonicity in $\mathrm{Cs}_{2} \mathrm{SnI}_{6}$ structure. (b) Variable temperature ${ }^{119} \mathrm{Sn} T_{1}$ data $\left(v_{\mathrm{r}}=\right.$ 
$0 \mathrm{kHz}, \mathrm{B}_{0}=11.75 \mathrm{~T}$ ) as a function of inverse of temperature for solvent synthesized $\mathrm{Cs}_{2} \mathrm{SnI}_{6}$.

Mechanochemically Synthesized $\mathrm{Cs}_{2} \mathrm{SnCl}_{x} \mathrm{Br}_{6-x}$ and $\boldsymbol{C s}_{2} \boldsymbol{S n B r}_{x} \boldsymbol{I}_{6-\boldsymbol{x}}$ Mixed-Halides. Halide perovskites are predominately prepared by solvent-assisted, high temperature or vapor deposition techniques. 1,83,84 Mechanochemical synthesis is an entrenched "greener" synthetic route to prepare a broad range of advanced functional materials, ${ }^{85-87}$ and has recently been applied successfully in large-scale production of perovskite photovoltaic materials. ${ }^{36,38,88-92}$ Moreover, certain compositions of $\mathrm{APbX}_{3}$ mixed-halide perovskites were achieved only by mechanochemical synthesis, but not via solvent-assisted routes. ${ }^{37,38,93}$

Both manual hand-grinding using mortar and pestle and automated electric ball-milling have been used as solvent-free mechanochemical synthesis routes to prepare bulk halide perovskites. ${ }^{16,36-38,89,90}$ Recently, we have shown that, using a hand-grinding approach, one can obtain phase pure $\mathrm{APbX}_{3}$ perovskites within hours. ${ }^{36-38}$ However, replacing lead(II) with tin(IV), we find that hand-grinding preparation of $\mathrm{Cs}_{2} \mathrm{SnI}_{6}$ requires a substantially longer mixing time $(6 \mathrm{~h})$. In comparison, electric ball-milling is more efficient (1.5 h) over the labor-intensive manual route (Figure S9). The phase pure $\mathrm{Cs}_{2} \mathrm{SnCl}_{\mathrm{x}} \mathrm{Br}_{6-\mathrm{x}}(\mathrm{x}=3)$ and $\mathrm{Cs}_{2} \mathrm{SnBr}_{\mathrm{x}} \mathrm{I}_{6-\mathrm{x}}(\mathrm{x}=0,1.5$, $3,4.5,6)$ samples were prepared by mechanochemical ballmilling under ambient conditions (detailed synthesis is discussed in SI; see Experimental, Table S5 and Figures S10S11).

Figure $5 \mathrm{a}$ shows photographs of the ball-milled $\mathrm{Cs}_{2} \mathrm{SnCl}_{\mathrm{x}} \mathrm{Br}_{6-\mathrm{x}}$ and $\mathrm{Cs}_{2} \mathrm{SnBr}_{\mathrm{x}} \mathrm{I}_{6-\mathrm{x}}$ samples and their associated colors consistent with the optical bandgaps. The samples are micron-sized particles having uniform distributions of the constituent elements ( $\mathrm{Cs}, \mathrm{Sn}, \mathrm{Cl}, \mathrm{Br}, \mathrm{I}$ ), as determined from elemental mapping images collected using FESEM (Figures $5 \mathrm{~b}$ and S12). The elemental compositions of mixedhalide analogues, as determined by EDS analysis, agree well with the nominal compositions (Table S2 and Figure S13).

The powder XRD patterns collected at room temperature are consistent with the cubic structure (space group $F m \overline{3} m$ ) for $\mathrm{Cs}_{2} \mathrm{SnCl}_{\mathrm{x}} \mathrm{Br}_{6-\mathrm{x}}$ and $\mathrm{Cs}_{2} \mathrm{SnBr}_{\mathrm{x}} \mathrm{I}_{6-\mathrm{x}}$ (Figures $5 \mathrm{c}$ and $\mathrm{S} 14$ ). The powder XRD peaks are shifted towards a higher diffraction angle (Figure $5 \mathrm{c}$ ), and the refined unit cell parameter increases as smaller halide ions are replaced with larger variants (Table S6). The unit cell parameter in $\mathrm{Cs}_{2} \mathrm{SnBr}_{\mathrm{x}} \mathrm{I}_{6-\mathrm{x}}$ against $\mathrm{Br}$ content shows no significant deviation from linearity, in agreement with Vegard's law (Figure 5e). This finding suggests that $\mathrm{Br}$ and I atoms are randomly mixed in $\mathrm{Cs}_{2} \mathrm{SnBr}_{\mathrm{x}} \mathrm{I}_{6-\mathrm{x}}$; consistent with our previous observations in lead-based mixed-halide perovskites. ${ }^{37,38}$

The optical absorption spectra show that the absorption edge shifts to lower energy with greater $\mathrm{Br}$ content in $\mathrm{Cs}_{2} \mathrm{SnCl}_{\mathrm{x}} \mathrm{Br}_{6-\mathrm{x}}$ and I content in $\mathrm{Cs}_{2} \mathrm{SnBr}_{\mathrm{x}} \mathrm{I}_{6-\mathrm{x}}$ (Figure $5 \mathrm{~d}$ ). As extracted from the Tauc plot of the direct bandgap, the optical bandgap values span about $3 \mathrm{eV}$ for these samples (Table S6 and Figure S15), which agrees well with the previous observations. ${ }^{64,94}$ The bandgap in the $\mathrm{Cs}_{2} \mathrm{SnBr}_{\mathrm{x}} \mathrm{I}_{6-\mathrm{x}}$ mixedhalide series decreases nonlinearly from $3.30 \mathrm{eV}$ for $\mathrm{Cs}_{2} \mathrm{SnBr}_{6}$ to $1.54 \mathrm{eV}$ for $\mathrm{Cs}_{2} \mathrm{SnI}_{6}$ (Figure $5 \mathrm{e}$ ). This behavior is different from the linear bandgap trend observed in leadcontaining mixed-halide perovskites, ${ }^{36-38}$ but is similar to the observed anomalous nonlinear trend in the mixed tinlead perovskites. ${ }^{95}$

A more complete local structural model for the mixed-halide samples can be obtained by solid-state ${ }^{133} \mathrm{Cs}$ and ${ }^{119} \mathrm{Sn}$ NMR spectroscopy to interrogate the A- and B-sites, respectively. Figure 6 a shows the ${ }^{133} \mathrm{Cs}$ MAS NMR spectra for $\mathrm{Cs}_{2} \mathrm{SnCl}_{\mathrm{x}} \mathrm{Br}_{6-\mathrm{x}}$ and $\mathrm{Cs}_{2} \mathrm{SnBr}_{\mathrm{x}} \mathrm{I}_{6-\mathrm{x}} . \mathrm{Cs}_{2} \mathrm{SnCl}_{3} \mathrm{Br}_{3}$ exhibits an inhomogeneously broadened ${ }^{133} \mathrm{Cs}$ NMR resonance $(\mathrm{fwhm}=1.1$ $\mathrm{kHz}$ ) due to the spectral overlap of multiple local $\mathrm{CsCl}_{m} \mathrm{Br}_{12-m}(m=0-12)$ halide environments according to the random distribution (Table S7 and Figure S16a). ${ }^{36}$ The ${ }^{133} \mathrm{Cs}$ SSB manifold is related to the local $\mathrm{CsX}_{12}$ cuboctahedral symmetry of perovskites, ${ }^{49}$ an increase in the ${ }^{133}$ Cs SSBs in $\mathrm{Cs}_{2} \mathrm{SnCl}_{3} \mathrm{Br}_{3}$ indicates a perturbation within the electric field gradient due to the lowering in the local cuboctahedral symmetry upon $\mathrm{Cl}$ and $\mathrm{Br}$ mixing, and hence an increase in the quadrupole coupling constant (Figure S17). For the $\mathrm{Cs}_{2} \mathrm{SnBr}_{\mathrm{x}} \mathrm{I}_{6-\mathrm{x}}$ series, the ${ }^{133} \mathrm{Cs}$ NMR resonances span across $160 \mathrm{ppm}$ between 115 to $-45 \mathrm{ppm}$. The resonances are either spectrally unresolved for Br-rich or resolved for I-rich samples (Figure 6a). The Br-rich sample, $\mathrm{Cs}_{2} \mathrm{SnBr}_{4.5} \mathrm{I}_{1.5}$, shows an inhomogeneously broadened ${ }^{133} \mathrm{Cs}$ NMR peak due to spectral overlapping of multiple local $\mathrm{CsBr}_{m} \mathrm{I}_{12-m}$ environments according to the random population distribution (Table S7 and Figure S16b), thereby limiting spectral resolution. $\mathrm{Cs}_{2} \mathrm{SnBr}_{3} \mathrm{I}_{3}$ which contains equal proportions of $\mathrm{Br}$ and I atoms, exhibits a partially spectrally resolved ${ }^{133} \mathrm{Cs}$ NMR resonance. Remarkably, the I-rich sample, $\mathrm{Cs}_{2} \mathrm{SnBr}_{1.5} \mathrm{I}_{4.5}$ shows spectrally resolved ${ }^{133} \mathrm{Cs}$ NMR resonances, which correspond to six distinguishably resolved local $\mathrm{CsBr}_{m} \mathrm{I}_{12-m}$ ( $m=0,1,2,3,4,5)$ environments (Figure 6b). The lowest chemical shift at $-38.4 \mathrm{ppm}(\mathrm{fwhm}=500 \mathrm{~Hz}$ ) is assigned to the $\mathrm{CsI}_{12}$ environment, which is comparable to the local chemical environment at $-41.5 \mathrm{ppm}$ ( $\mathrm{fwhm}=110 \mathrm{~Hz}$ ) for $\mathrm{Cs}_{2} \mathrm{SnI}_{6}$ parent (Figure 6a). The observed broadening and shift of the resonance to higher frequency is associated with the lower site symmetry than cubic as the next-nearest neighbors in the medium-range structure ( $>5 \AA$ ) consists of a mixture of $\mathrm{Br}$ and I atoms. ${ }^{49}$ The remaining peaks within the sets of ${ }^{133} \mathrm{Cs}$ resonances in $\mathrm{Cs}_{2} \mathrm{SnBr}_{1.5} \mathrm{I}_{4.5}$ shift towards higher frequency as I is substituted by $\mathrm{Br}$ (Figure $6 \mathrm{c}$ and Table S8), following a strict linear dependence [Eq (1)] with $m$ in $\mathrm{CsBr}_{m} \mathrm{I}_{12-m}$.

$$
\delta\left({ }^{133} \mathrm{Cs}\right) / \mathrm{ppm}=17.0 \cdot \mathrm{m}-36.78
$$

Furthermore, the observation of increasing ${ }^{133} \mathrm{Cs}$ linewidth for $\mathrm{CsBr}_{m} \mathrm{I}_{12-m}$ peaks with increased $\mathrm{Br}$ content (Table S8) suggests the spectral overlap of multiple positional isomers for unique $\mathrm{CsBr}_{m} \mathrm{I}_{12-m}$ environments that consists of a mixture of $\mathrm{Br}$ and I atoms in 12 positions. The ${ }^{133} \mathrm{Cs}$ spin-lattice relaxation times decrease linearly from 40 to $14 \mathrm{~s}$ with increase in number of $\mathrm{Br}$ attached in $\mathrm{CsBr}_{m} \mathrm{I}_{12-m}$ (Figure 6c). Acquiring the ${ }^{133} \mathrm{Cs}$ NMR spectra with a quantitative recycle delay for $\mathrm{Cs}_{2} \mathrm{SnBr}_{1.5} \mathrm{I}_{4.5}$ (Figure $\mathrm{S} 18$ ), the fitted ${ }^{133} \mathrm{Cs}$ peak areas for each $\mathrm{CsBr}_{m} \mathrm{I}_{12-m}$ environment closely follow a binomial population distribution (Figure $6 \mathrm{~d}$ and Table S8). This observation is consistent with random $\mathrm{Br}$ and I mixing at the local structure, forming an atomic-level mixed-halide 
solid-solution without evidence of halogen-rich phase segregation or domains.

The ${ }^{119} \mathrm{Sn}$ NMR spectra for the $\mathrm{Cs}_{2} \mathrm{SnCl}_{\mathrm{x}} \mathrm{Br}_{6-\mathrm{x}}$ and $\mathrm{Cs}_{2} \mathrm{SnBr}_{\mathrm{x}} \mathrm{I}_{6-\mathrm{x}}$ series are fascinating and, exhibit broad (100s of $\mathrm{kHz}$ ) and partial spectrally resolved multiple ${ }^{119} \mathrm{Sn}$ resonances (Figure 7). To achieve maximum ${ }^{119} \mathrm{Sn}$ NMR sensitivity, optimized ${ }^{119} \mathrm{Sn}$ recycle delays and variable offset cumulative spectra (if required) were used due to their drastic differences in ${ }^{119} \mathrm{Sn} T_{1}$ and large chemical shift spans, respectively
(Table S9d). This observation contrasts with the recent observations on $\mathrm{ASnX}_{3}$ mixed-halide perovskites, where single ${ }^{119} \mathrm{Sn}$ resonances are reported due to rapid halogen dynamics. ${ }^{16,17}$ However, the broadening and multi resonance spectral behavior agrees well with ${ }^{207} \mathrm{~Pb} \mathrm{NMR}$ spectra for $\mathrm{APbX}_{3}$ mixed-halide perovskites. ${ }^{36-38}$ 

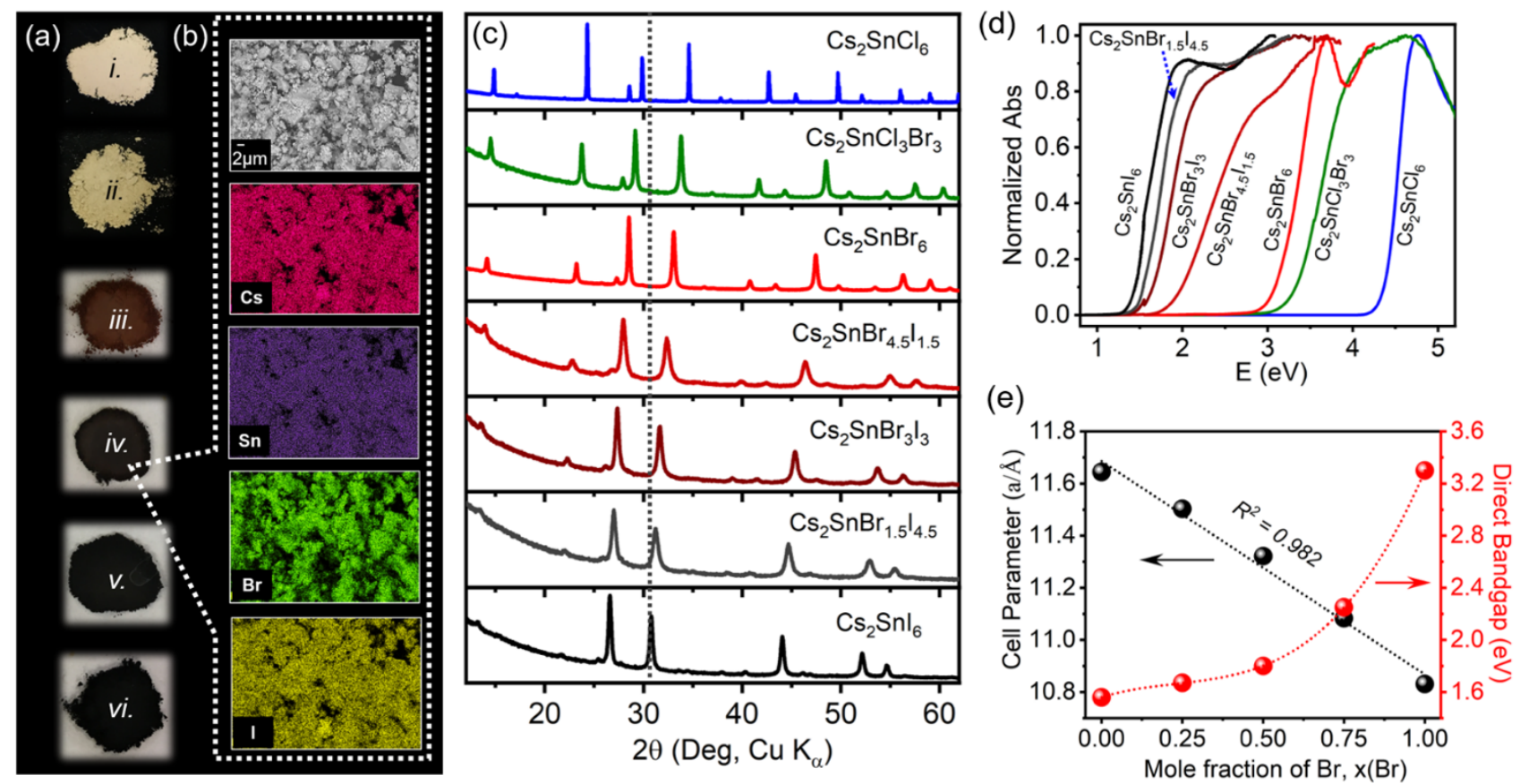

Figure 5. (a) Photographs of ball-milled samples: (i) $\mathrm{Cs}_{2} \mathrm{SnCl}_{3} \mathrm{Br}_{3}$, (ii) $\mathrm{Cs}_{2} \mathrm{SnBr}_{6}$, (iii) $\mathrm{Cs}_{2} \mathrm{SnBr}_{1.5} \mathrm{I}_{4.5}$, (iv) $\mathrm{Cs}_{2} \mathrm{SnBr}_{3} \mathrm{I}_{3}$, (v) $\mathrm{Cs}_{2} \mathrm{SnBr}_{1.5} \mathrm{I}_{4.5}$ and (vi) $\mathrm{Cs}_{2} \mathrm{SnI}_{6}$. (b) Scanning electron micrograph and elemental mapping for $\mathrm{Cs}_{2} \mathrm{SnBr}_{3} \mathrm{I}_{3}$. (c) Powder XRD patterns, (d) normalized optical absorption spectra of ball-milled $\mathrm{Cs}_{2} \mathrm{SnCl}_{x} \mathrm{Br}_{6-x}$ and $\mathrm{Cs}_{2} \mathrm{SnBr}_{x} \mathrm{I}_{6-x}$ samples (except $\mathrm{Cs}_{2} \mathrm{SnCl}_{6}$, solvent synthesized). (e) Plots of unit cell parameters and bandgaps of ball-milled $\mathrm{Cs}_{2} \mathrm{SnBr}_{\mathrm{x}} \mathrm{I}_{6-\mathrm{x}}$ series.

(a)
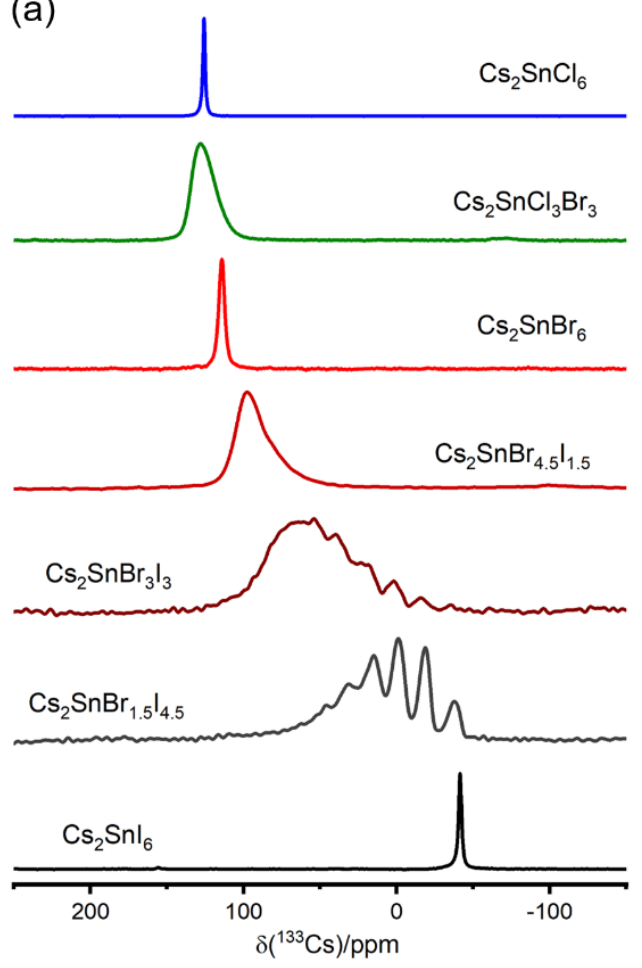

(b)

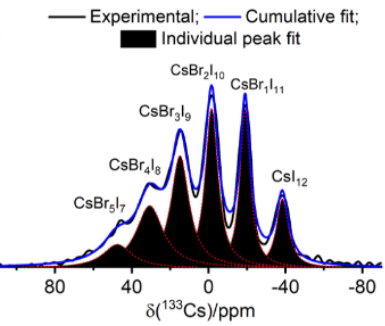

(c)

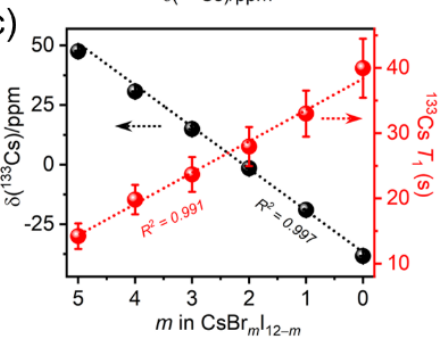

(d)

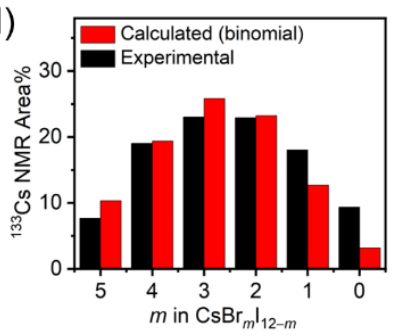

Figure 6. (a) Solid-state ${ }^{133} \mathrm{Cs}\left(v_{\mathrm{r}}=13 \mathrm{kHz}, \mathrm{B}_{0}=11.75 \mathrm{~T}\right.$ ) NMR spectra of ball-milled $\mathrm{Cs}_{2} \mathrm{SnCl}_{\mathrm{x}} \mathrm{Br}_{6-\mathrm{x}}$ and $\mathrm{Cs}_{2} \mathrm{SnBr}_{\mathrm{x}} \mathrm{I}_{6-\mathrm{x}}$ samples (except $\mathrm{Cs}_{2} \mathrm{SnCl}_{6}$, solvent synthesized). (b) Experimental and fitted ${ }^{133} \mathrm{Cs}$ NMR spectra, (c) ${ }^{133} \mathrm{Cs}$ chemical shift and ${ }^{133} \mathrm{Cs}$ fwhm values and (d) population distribution as a function of $\mathrm{Br}$ atoms in $\mathrm{CsBr}_{m} \mathrm{I}_{12-m}$ for $\mathrm{Cs}_{2} \mathrm{SnBr}_{1.5} \mathrm{I}_{4.5}$. 
(a)

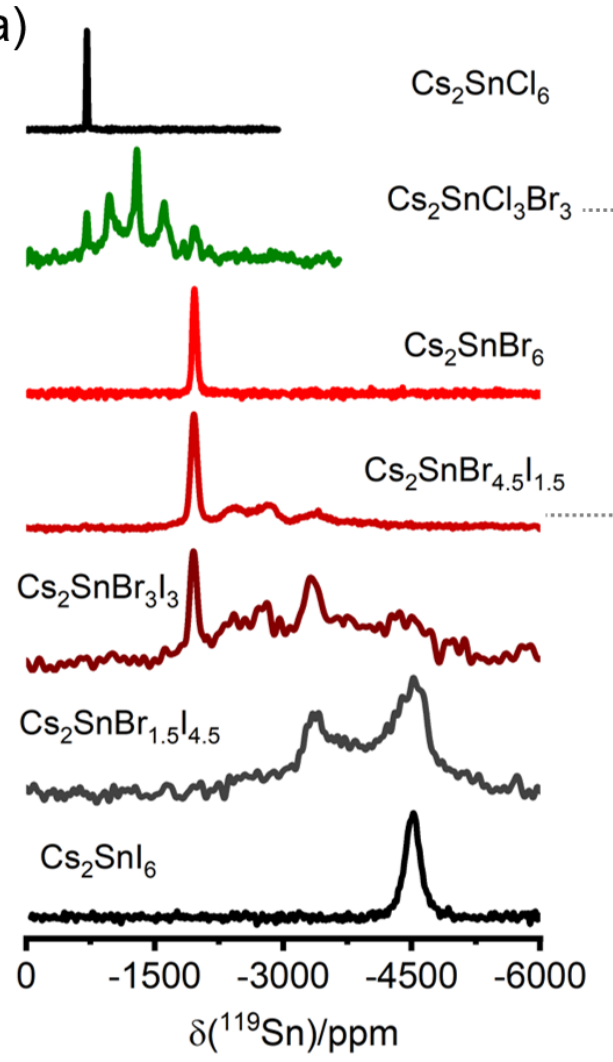

(b)

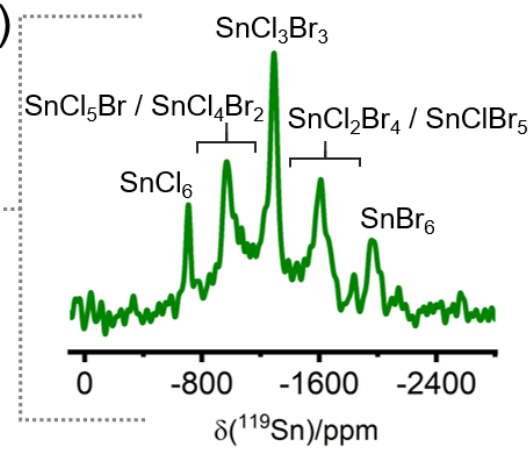

(c)

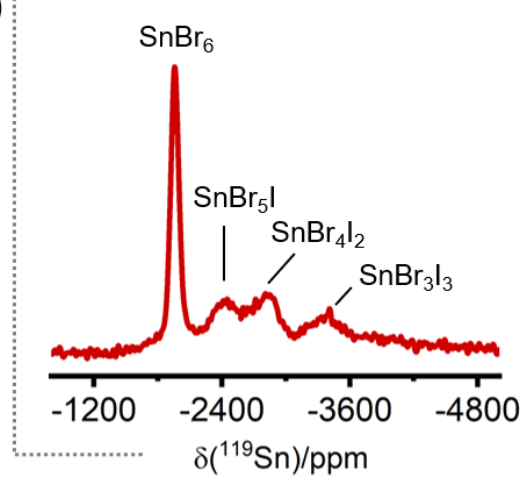

Figure 7. Solid-state ${ }^{119} \mathrm{Sn}$ (non-spinning, $\mathrm{B}_{0}=7.05 \mathrm{~T}$ ) NMR spectra of (a) ball-milled $\mathrm{Cs}_{2} \mathrm{SnCl}_{\mathrm{x}} \mathrm{Br}_{6-\mathrm{x}}$ and $\mathrm{Cs}_{2} \mathrm{SnBr}_{\mathrm{x}} \mathrm{I}_{6-\mathrm{x}}\left(\mathrm{except} \mathrm{Cs}_{2} \mathrm{SnCl}_{6}\right.$, solvent synthesized), (b) $\mathrm{Cs}_{2} \mathrm{SnCl}_{3} \mathrm{Br}_{3}$ and (c) $\mathrm{Cs}_{2} \mathrm{SnBr}_{4.5} \mathrm{I}_{1.5}$. The local $\mathrm{SnCl}_{n} \mathrm{Br}_{6-n}$ and $\mathrm{SnBr}_{n} \mathrm{I}_{6-n}$ environments are assigned in (b) and (c).

To understand the observed ${ }^{119} \mathrm{Sn}$ NMR spectra for mixedhalide analogues, the ${ }^{119} \mathrm{Sn}$ magnetic shielding parameters of isolated octahedral clusters, i.e., $\operatorname{SnCl}_{n} \mathrm{Br}_{6-n}(n=0-6)$ for $\mathrm{Cs}_{2} \mathrm{SnCl}_{x} \mathrm{Br}_{6-\mathrm{x}}$ and $\mathrm{SnBr}_{n} \mathrm{I}_{6-n}$ for $\mathrm{Cs}_{2} \mathrm{SnBr}_{\mathrm{x}} \mathrm{I}_{6-\mathrm{x}}$ were computed using DFT and the computational details are provided in the SI (see Experimental, Tables S10-S11). The computed ${ }^{119} \mathrm{Sn}$ isotropic chemical shifts are linearly shifted to lower frequency as $\mathrm{Cl}$ is substituted by $\mathrm{Br}$ in $\mathrm{SnCl}_{n} \mathrm{Br}_{6-n}$ (Figure 8a) and $\mathrm{Br}$ is substituted by $\mathrm{I}$ in $\mathrm{SnBr}_{n} \mathrm{I}_{6-n}$ (Figure S19). The computed magnetic shielding anisotropy parameters (span and skew) exhibit a wide range of values that exclusively depend on $n$ values and their positional isomers (cis/trans or fac/mer) in $\mathrm{SnCl}_{n} \mathrm{Br}_{6-n}$ and $\mathrm{SnBr}_{n} \mathrm{I}_{6-n}$; this is responsible for broader NMR linewidths (Figures 7, 8 and S20). For example, the computed ${ }^{119} \mathrm{Sn}$ span is $1058 \mathrm{ppm}$ for trans- $\mathrm{SnCl}_{2} \mathrm{Br}_{4}$ in $\mathrm{Cs}_{2} \mathrm{SnCl}_{\mathrm{x}} \mathrm{Br}_{6-\mathrm{x}}$ and up to $4702 \mathrm{ppm}$ for trans-SnI $\mathrm{Br}_{2}$ in $\mathrm{Cs}_{2} \mathrm{SnBr}_{\mathrm{x}} \mathrm{I}_{6-\mathrm{x}}$. The experimentally observed ${ }^{119} \mathrm{Sn}$ NMR spectra in $\mathrm{Cs}_{2} \mathrm{SnCl}_{\mathrm{x}} \mathrm{Br}_{6-\mathrm{x}}$ and $\mathrm{Cs}_{2} \mathrm{SnBr}_{\mathrm{x}} \mathrm{I}_{6-\mathrm{x}}$ are a combination of individual resonances of all possible $\mathrm{SnCl}_{n} \mathrm{Br}_{6-n}$ or $\mathrm{SnBr}_{n} \mathrm{I}_{6-n}$ species according to their populations following a random distribution (Table S12 and Figure S21). Along with magnetic shielding anisotropy, the experimental NMR spectra get further broadened by both indirect and direct spin-spin coupling between ${ }^{119} \mathrm{Sn}$ and six quadrupolar halogens $\left({ }^{35 / 37} \mathrm{Cl},{ }^{79 / 81} \mathrm{Br}\right.$ and $\left.{ }^{127} \mathrm{I}\right)$ in $\mathrm{SnCl}_{n} \mathrm{Br}_{6-n}$ or $\mathrm{SnBr}_{n} \mathrm{I}_{6-n}$, vide supra. Due to the complex nature of these parameters, inability to acquire ultrafast MAS and less spectral resolution among ten possible unique halide arrangements including the isomers in $\mathrm{SnCl}_{n} \mathrm{Br}_{6-n}$ or $\mathrm{SnBr}_{n} \mathrm{I}_{6-n}$, we refrain from quantitively deconvoluting the experimental ${ }^{119} \mathrm{Sn}$ NMR spectra for $\mathrm{Cs}_{2} \mathrm{SnCl}_{\mathrm{x}} \mathrm{Br}_{6-\mathrm{x}}$ and $\mathrm{Cs}_{2} \mathrm{SnBr}_{\mathrm{x}} \mathrm{I}_{6-\mathrm{x}}$ but these are discussed qualitatively below.

The multiple ${ }^{119} \mathrm{Sn}$ peaks in mixed-halide samples correspond to several distinct local Sn octahedral environments. Guided by the DFT computations, the five spectrally distinguishable ${ }^{119} \mathrm{Sn}$ NMR resonances in $\mathrm{Cs}_{2} \mathrm{SnCl}_{3} \mathrm{Br}_{3}$ are tentatively assigned as the spectral regions for $\mathrm{SnCl}_{6}(-707 \mathrm{ppm})$, $\mathrm{SnCl}_{5} \mathrm{Br}_{1} / \mathrm{SnCl}_{4} \mathrm{Br}_{2}$ (-966 ppm), $\mathrm{SnCl}_{3} \mathrm{Br}_{3}(-1291 \mathrm{ppm})$, $\mathrm{SnCl}_{2} \mathrm{Br}_{4} / \mathrm{SnCl}_{1} \mathrm{Br}_{5}(-1610 \mathrm{ppm})$ and $\operatorname{SnBr}_{6}(-1962 \mathrm{ppm})$ (Figure 7b). The ${ }^{119} \mathrm{Sn}$ NMR spectra for $\mathrm{Cs}_{2} \mathrm{SnBr}_{\mathrm{x}} \mathrm{I}_{6-\mathrm{x}}$ get much broader and unresolved due to the stronger ${ }^{1} J\left({ }^{119} \mathrm{Sn}-79 / 81 \mathrm{Br}\right)$ and ${ }^{1} J\left({ }^{119} \mathrm{Sn}-{ }^{127} \mathrm{I}\right)$ in $\mathrm{SnBr}_{n} \mathrm{I}_{6-n}$ along with their higher magnetic shielding anisotropy (1000s ppm) predicted by DFT (Table S10). Nevertheless, four spectrally resolved ${ }^{119} \mathrm{Sn}$ NMR resonances can be tentatively assigned in Br-rich $\mathrm{Cs}_{2} \mathrm{SnBr}_{4.5} \mathrm{I}_{1.5}$ as the spectral regions for $\mathrm{SnBr}_{6}$ (-1962 ppm), $\mathrm{SnBr}_{5} \mathrm{I}_{1}(-2434 \mathrm{ppm}), \mathrm{SnBr}_{4} \mathrm{I}_{2}(-2842 \mathrm{ppm})$ and $\mathrm{SnBr}_{3} \mathrm{I}_{3}(-3378 \mathrm{ppm})$ environments (Figure $\left.7 \mathrm{c}\right)$.

Influence of Synthesis Routes on Local Structure of $\boldsymbol{C S}_{2} \boldsymbol{S n I}_{6}$. A feature of photovoltaic perovskites is that they can be synthesized by various avenues, with or without solvents; however, the local chemical structure resulting from these approaches is poorly understood. Thus, to elucidate 
the structure, solid-state ${ }^{133} \mathrm{Cs}$ and ${ }^{119} \mathrm{Sn}$ NMR spectroscopy was performed for three $\mathrm{Cs}_{2} \mathrm{SnI}_{6}$ samples prepared by three different preparation techniques, namely, solvent-free ballmilling, hand-grinding, and solvent-assisted synthesis routes.

\section{(a)}

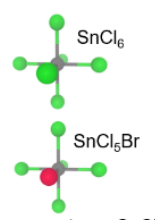

cis- $\mathrm{SnCl}_{4} \mathrm{Br}_{2}$ trans- $\mathrm{SnCl}_{4} \mathrm{Br}_{2}$

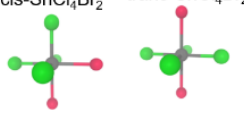

fac- $\mathrm{SnCl}_{3} \mathrm{Br}_{3} \quad$ mer- $-\mathrm{SnCl}_{3} \mathrm{Br}_{3}$

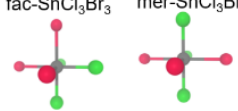

cis- $\mathrm{SnCl}_{2} \mathrm{Br}_{4}$ trans- $\mathrm{SnCl}_{2} \mathrm{Br}_{4}$
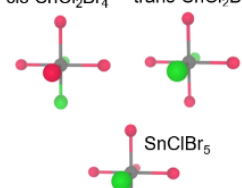

4

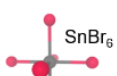

(b)

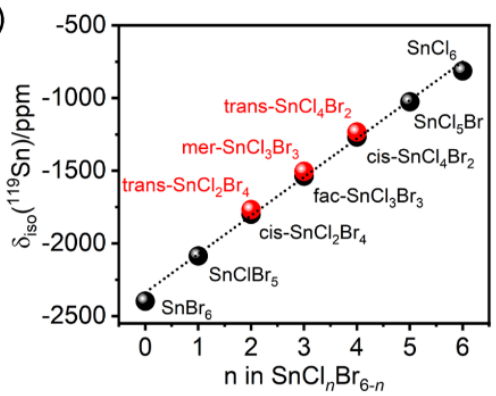

(c)

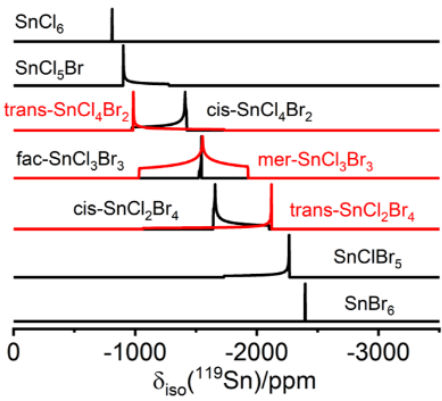

Figure 8. DFT computed results for $\mathrm{SnCl}_{n} \mathrm{Br}_{6-n}$ : (a) optimized geometries, (b) ${ }^{119} \mathrm{Sn}$ isotropic chemical shift as a function of number of $\mathrm{Cl}$ and (b) simulated ${ }^{119} \mathrm{Sn}$ NMR spectra.

The ${ }^{133} \mathrm{Cs}$ NMR spectra of these three $\mathrm{Cs}_{2} \mathrm{SnI}_{6}$ samples show resonances in the same spectral positions with nearly identical linewidths (Figure 9a). However, the slight asymmetry of the underlying ${ }^{133} \mathrm{Cs}$ resonance for the ball-milled sample corresponds to higher local structural disorder and smaller average crystallite sizes as compared to solvent-synthesized and hand-ground samples. The ${ }^{119} \mathrm{Sn}$ NMR spectra for all three $\mathrm{Cs}_{2} \mathrm{SnI}_{6}$ samples show symmetric resonances with different chemical shifts and linewidths (Figure 9b). The solvent-synthesized and hand-ground samples exhibit sharper resonances at $-4535 \mathrm{ppm}(\mathrm{fwhm}=17 \mathrm{kHz})$ and $-4527 \mathrm{ppm}(\mathrm{fwhm}=17 \mathrm{kHz})$, respectively, whereas, the ball-milled sample shows a broad resonance at $-4505 \mathrm{ppm}$ (fwhm $=20 \mathrm{kHz}$ ). The sharper ${ }^{119} \mathrm{Sn}$ resonance indicates that the solvent-synthesized sample has a well-ordered structure with minimum defects, whereas, the broader ${ }^{119} \mathrm{Sn}$ resonance indicates the presence of the higher defect concentration in the ball-milled sample. The ball-milling is a high energy grinding technique that causes grinding-induced defects as compared to the low energy manual handgrinding route. The ${ }^{119} \mathrm{Sn}$ spin-lattice relaxation depends significantly on the synthesis routes with $T_{1}=0.01 \mathrm{~s}$ for the ball-milled sample, which is an order of magnitude less than that of the solvent synthesized counterpart. The faster relaxation process for the ball-milled sample supports higher local structural disorder or defects which is consistent with the conclusion based on ${ }^{119} \mathrm{Sn}$ NMR linewidths.

The higher structural disorder is also reflected in broader peaks in powder XRD patterns for the ball-milled sample as compared to the well structurally ordered solvent-synthesized sample (Figure S22). The different degrees of crystallinity in $\mathrm{Cs}_{2} \mathrm{SnI}_{6}$ samples also affects the optical absorption properties, with bandgaps of $1.56 \mathrm{eV}$ for the ball-milled sample and $1.42 \mathrm{eV}$ for the solvent-synthesized sample.
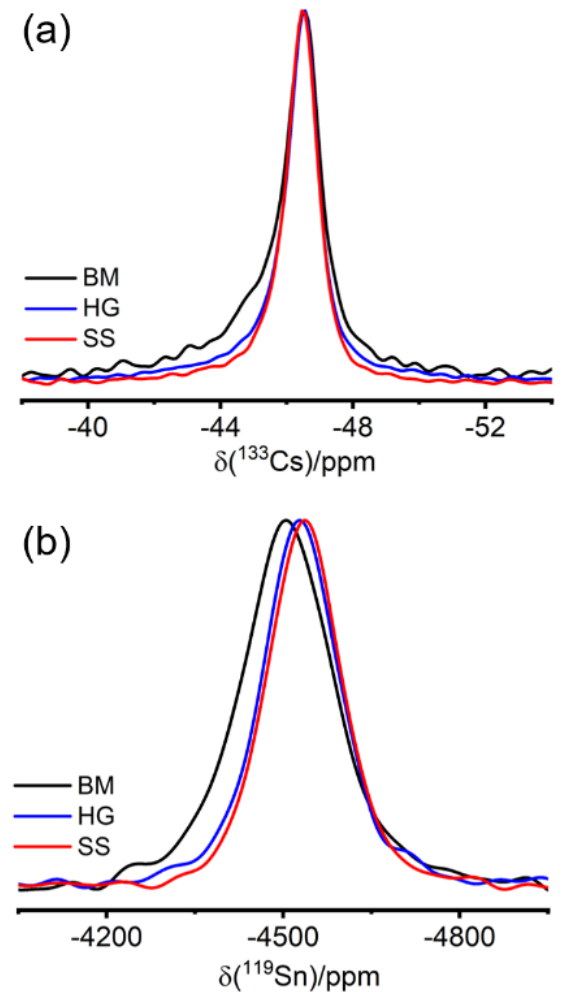

Figure 9. Solid-state (a) ${ }^{133} \mathrm{Cs}\left(v_{\mathrm{r}}=5 \mathrm{kHz}, \mathrm{B}_{0}=11.75 \mathrm{~T}\right)$ and $(\mathrm{b})$ ${ }^{119} \mathrm{Sn}$ (non-spinning, $\mathrm{B}_{0}=7.05 \mathrm{~T}$ ) NMR spectra of $\mathrm{Cs}_{2} \mathrm{SnI}_{6}$ samples prepared by solvent-synthesis (SS), hand-grinding (HG), and ball-milling (BM) routes.

\section{CONCLUSIONS}

The macro to microscopic structures and bulk photophysical properties for $\mathrm{Cs}_{2} \mathrm{SnX}_{6}(\mathrm{X}=\mathrm{Cl}, \mathrm{Br}, \mathrm{I})$ parent perovskites prepared by the solvent-assisted synthesis route were evaluated using powder XRD and multinuclear magnetic resonance spectroscopy. Tin-119 NMR spectroscopy revealed a massive chemical shift range spanning $\mathrm{ca} .4000 \mathrm{ppm}$ that, according to DFT computations, is dominated by a large spin-orbit component. Likewise, the ${ }^{119} \mathrm{Sn}$ spin-lattice relaxation times change by three orders of magnitude for these materials as the halide anion increases in size. The ${ }^{35} \mathrm{Cl}$ quadrupole coupling constant for $\mathrm{Cs}_{2} \mathrm{SnCl}_{6}$ is nearly double that for the hybrid and non-hybrid lead(II) chloride perovskites, $\mathrm{APbCl}_{3}$, consistent with $\mathrm{Cl}$ bound to $\mathrm{Sn}$ in a 4+ oxidation state. The rapid octahedral dynamics of SnI6 units in $\mathrm{Cs}_{2} \mathrm{SnI}_{6}$ are remarkable, displaying a low activation energy $(12.45 \pm 0.87 \mathrm{~kJ} / \mathrm{mol})$ for the polyhedral motion in these stable "static" solids.

The complete solid solutions $\mathrm{Cs}_{2} \mathrm{SnCl}_{x} \mathrm{Br}_{6-\mathrm{x}}$ and $\mathrm{Cs}_{2} \mathrm{SnBr}_{\mathrm{x}} \mathrm{I}_{6-\mathrm{x}}$ $(0 \leq \mathrm{x} \leq 6)$ mixed-halides that exhibit attractive optical 
bandgaps spanning approximately $3 \mathrm{eV}$, were successfully prepared by a solvent-free ball-milling synthesis route at room temperature. According to solid-state ${ }^{133} \mathrm{Cs}$ and ${ }^{119} \mathrm{Sn}$ NMR spectroscopy, the mixed-halide analogues undergo a complete random distribution of $\mathrm{Cl} / \mathrm{Br}$ or $\mathrm{Br} / \mathrm{I}$ halogens at the atomic level, with no evidence of halogen-rich phase segregation or domains under dark conditions. Furthermore, the broad ${ }^{119} \mathrm{Sn}$ NMR resonances observed in mixedhalide samples, supported by magnetic shielding parameters obtained by DFT, assisted in assigning the unique Sn chemical environments, supporting the complex nature one must contend with due to considerable shielding anisotropy.

The bulk optical bandgap properties for the $\mathrm{Cs}_{2} \mathrm{SnI}_{6}$ samples prepared by solvent-free and solvent-assisted synthesis routes are sensitive to local structural changes as confirmed by NMR. For example, materials prepared by high energy ball-milling tend to show a lower degree of crystallinity (i.e., higher local structural disorder), resulting in faster ${ }^{119} \mathrm{Sn}$ relaxation and a slight increase in the bandgap $(0.14 \mathrm{eV})$ compared to the solvent-synthesized counterpart. Overall, solid-state NMR spectroscopy, alongside PXRD and DFT bestows unprecedented ability to unravel the complex chemical structure and dynamics present within vacancy-ordered double perovskite materials, whereby random halide arrangements and defects govern the optical bandgaps.

\section{ASSOCIATED CONTENT}

\section{Supporting Information.}

Detailed discussion of synthesis, experimental techniques, DFT computations, Tables S1-S12 and Figures S1-S22 are available in the Supporting Information (PDF).

\section{AUTHOR INFORMATION}

\section{Corresponding Author}

*e-mail: vladimir.michaelis@ualberta.ca

\section{Author Contributions}

All authors have given approval to the final version of the manuscript.

Notes

The authors declare no competing financial interest.

\section{ACKNOWLEDGMENT}

We acknowledge the Natural Sciences and Engineering Research Council (NSERC) of Canada, Canada Foundation for Innovation, Government of Alberta, Future Energy Systems (CFREF), CREATE (ATUMS) and the University of Alberta for research support. AK acknowledges an Alberta Innovates Graduate Scholarship. VAMG is supported by a Consejo Nacional de Ciencia y Tecnologia (CONACyT), scholarship No. 291163. A part of the research was carried out on computational resources provided by Compute Canada/ Calcul Canada (www.computecanada.ca).

\section{REFERENCES}

(1) Zhao, Y.; Zhu, K. Organic-Inorganic Hybrid Lead Halide Perovskites for Optoelectronic and Electronic Applications. Chem. Soc. Rev. 2016, 45, 655-689.

(2) Miao, Y.; Ke, Y.; Wang, N.; Zou, W.; Xu, M.; Cao, Y.; Sun, Y.; Yang, R.; Wang, Y.; Tong, Y.; Xu, W.; Zhang, L.; Li, R.; Li, J.; He, H.; Jin, Y.;
Gao, F.; Huang, W.; Wang, J. Stable and Bright FormamidiniumBased Perovskite Light-Emitting Diodes with High Energy Conversion Efficiency. Nat. Commun. 2019, 10, 3624.

(3) Wei, H.; Huang, J. Halide Lead Perovskites for Ionizing Radiation Detection. Nat. Commun. 2019, 10, 1066.

(4) Chen, K.; Deng, X.; Dodekatos, G.; Tüysüz, H. Photocatalytic Polymerization of 3,4-Ethylenedioxythiophene over Cesium Lead Iodide Perovskite Quantum Dots. J. Am. Chem. Soc. 2017, 139, 12267-12273.

(5) Babu, R.; Giribabu, L.; Singh, S. P. Recent Advances in HalideBased Perovskite Crystals and Their Optoelectronic Applications. Cryst. Growth Des. 2018, 18, 2645-2664.

(6) Kovalenko, M. V; Protesescu, L.; Bodnarchuk, M. I. Properties and Potential Optoelectronic Applications of Lead Halide Perovskite Nanocrystals. Science 2017, 750, 745-750.

(7) National Renewable Energy Laboratory (NREL). Best ResearchCell Efficiency Chart. https://www.nrel.gov/pv/assets/pdfs/best-research-cellefficiencies.20200104.pdf (accessed March 2021).

(8) Berhe, T. A.; Su, W. N.; Chen, C. H.; Pan, C. J.; Cheng, J. H.; Chen, H. M.; Tsai, M. C.; Chen, L. Y.; Dubale, A. A.; Hwang, B. J. Organometal Halide Perovskite Solar Cells: Degradation and Stability. Energy Environ. Sci. 2016, 9, 323-356.

(9) Yang, J.; Siempelkamp, B. D.; Liu, D.; Kelly, T. L. Investigation of $\mathrm{CH}_{3} \mathrm{NH}_{3} \mathrm{PbI}_{3}$ degradation Rates and Mechanisms in Controlled Humidity Environments Using in Situ Techniques. ACS Nano 2015, 9, 1955-1963.

(10) Domanski, K.; Alharbi, E. A.; Hagfeldt, A.; Grätzel, M.; Tress, W. Systematic Investigation of the Impact of Operation Conditions on the Degradation Behaviour of Perovskite Solar Cells. Nat. Energy 2018, 3, 61-67.

(11) Askar, A. M.; Bernard, G. M.; Wiltshire, B.; Shankar, K.; Michaelis, V. K. Multinuclear Magnetic Resonance Tracking of Hydro, Thermal, and Hydrothermal Decomposition of $\mathrm{CH}_{3} \mathrm{NH}_{3} \mathrm{PbI}_{3}$. J. Phys. Chem. C 2017, 121, 1013-1024.

(12) Li, J.; Cao, H.; Jiao, W.; Wang, Q.; Wei, M.; Cantone, I.; Lü, J.; Abate A. Biological Impact of Lead from Halide Perovskites Reveals the Risk of Introducing a Safe Threshold. Nat. Commun. 2020, 11, 310.

(13) Babayigit, A.; Ethirajan, A.; Muller, M.; Conings, B. Toxicity of Organometal Halide Perovskite Solar Cells. Nat. Mater. 2016, 15, 247-251.

(14) Kamarudin, M. A.; Hirotani, D.; Wang, Z.; Hamada, K.; Nishimura, K.; Shen, Q.; Toyoda, T.; Iikubo, S.; Minemoto, T.; Yoshino, K.; Hayase, S. Suppression of Charge Carrier Recombination in LeadFree Tin Halide Perovskite via Lewis Base Post-Treatment. J. Phys. Chem. Lett. 2019, 10, 5277-5283.

(15) Song, T. Bin; Yokoyama, T.; Stoumpos, C. C.; Logsdon, J.; Cao, D. H.; Wasielewski, M. R.; Aramaki, S.; Kanatzidis, M. G. Importance of Reducing Vapor Atmosphere in the Fabrication of Tin-Based Perovskite Solar Cells. J. Am. Chem. Soc. 2017, 139, 836-842.

(16) Kubicki, D. J.; Prochowicz, D.; Salager, E.; Rakhmatullin, A.; Grey, C. P.; Emsley, L.; Stranks, S. D. Local Structure and Dynamics in Methylammonium, Formamidinium and Cesium Tin(II) Mixed-halide Perovskites from ${ }^{119} \mathrm{Sn}$ Solid-state NMR. J. Am. Chem. Soc. 2020, 142, 7813-7826.

(17) Karmakar, A.; Bhattacharya, A.; Sarkar, D.; Bernard, G. M.; Mar, A.; Michaelis, V. K. Influence of Hidden Halogen Mobility on Local Structure of $\mathrm{CsSn}\left(\mathrm{Cl}_{1-\mathrm{x}} \mathrm{Br}_{\mathrm{x}}\right)_{3}$ Mixed-Halide Perovskites by SolidState NMR. Chem. Sci. 2021, 12, 3253-3263.

(18) Maughan, A. E.; Ganose, A. M.; Scanlon, D. O.; Neilson, J. R. Perspectives and Design Principles of Vacancy-Ordered Double Perovskite Halide Semiconductors. Chem. Mater. 2019, 31, 1184-1195.

(19) Brik, M. G.; Kityk, I. V. Modeling of Lattice Constant and Their Relations with Ionic Radii and Electronegativity of Constituting Ions of $\mathrm{A}_{2} \mathrm{XY}_{6}$ Cubic Crystals $(\mathrm{A}=\mathrm{K}, \mathrm{Cs}, \mathrm{Rb}, \mathrm{Tl}$; $\mathrm{X}=$ tetravalent Cation, Y=F, Cl, Br, I). J. Phys. Chem. Solids 2011, 72, 1256-1260.

(20) Saparov, B.; Sun, J. P.; Meng, W.; Xiao, Z.; Duan, H. S.; Gunawan, O.; Shin, D.; Hill, I. G.; Yan, Y.; Mitzi, D. B. Thin-Film Deposition and Characterization of a Sn-Deficient Perovskite Derivative $\mathrm{Cs}_{2} \mathrm{SnI}_{6}$. Chem. Mater. 2016, 28, 2315-2322. 
(21) Maughan, A. E.; Ganose, A. M.; Bordelon, M. M.; Miller, E. M.; Scanlon, D. O.; Neilson, J. R. Defect Tolerance to Intolerance in the Vacancy-Ordered Double Perovskite Semiconductors $\mathrm{Cs}_{2} \mathrm{SnI}_{6}$ and $\mathrm{Cs}_{2} \mathrm{TeI}_{6}$. J. Am. Chem. Soc. 2016, 138, 8453-8464.

(22) Lee, B.; Stoumpos, C. C.; Zhou, N.; Hao, F.; Malliakas, C.; Yeh, C. Y.; Marks, T. J.; Kanatzidis, M. G.; Chang, R. P. H. Air-Stable Molecular Semiconducting Iodosalts for Solar Cell Applications: $\mathrm{Cs}_{2} \mathrm{SnI}_{6}$ as a Hole Conductor. J. Am. Chem. Soc. 2014, 136, 15379-15385.

(23) Lee, B.; Krenselewski, A.; Baik, S. Il; Seidman, D. N.; Chang, R. P. H. Solution Processing of Air-Stable Molecular Semiconducting Iodosalts, $\mathrm{Cs}_{2} \mathrm{SnI}_{6-\mathrm{x}} \mathrm{Br}_{\mathrm{x}}$, for Potential Solar Cell Applications. Sustain. Energy Fuels 2017, 1, 710-724.

(24) Kaltzoglou, A.; Antoniadou, M.; Perganti, D.; Siranidi, E.; Raptis, V.; Trohidou, K.; Psycharis, V.; Kontos, A. G.; Falaras, P. MixedHalide $\mathrm{Cs}_{2} \mathrm{SnI}_{3} \mathrm{Br}_{3}$ Perovskite as Low Resistance HoleTransporting Material in Dye-Sensitized Solar Cells. Electrochim. Acta 2015, 184, 466-474.

(25) Wang, A.; Yan, X.; Zhang, M.; Sun, S.; Yang, M.; Shen, W.; Pan, X.; Wang, P.; Deng, Z. Controlled Synthesis of Lead-Free and Stable Perovskite Derivative $\mathrm{Cs}_{2} \mathrm{SnI}_{6}$ Nanocrystals via a Facile HotInjection Process. Chem. Mater. 2016, 28, 8132-8140.

(26) Lim, S. C.; Lin, H. P.; Tsai, W. L.; Lin, H. W.; Hsu, Y. T.; Tuan, H. Y. Binary Halide, Ternary Perovskite-like, and PerovskiteDerivative Nanostructures: Hot Injection Synthesis and Optical and Photocatalytic Properties. Nanoscale 2017, 9, 3747-3751.

(27) Veronese, A.; Patrini, M.; Bajoni, D.; Ciarrocchi, C.; Quadrelli, P.; Malavasi, L. Highly Tunable Emission by Halide Engineering in Lead-Free Perovskite-Derivative Nanocrystals: $\mathrm{The} \mathrm{Cs}_{2} \mathrm{SnX}_{6}$ (X = $\mathrm{Cl}, \mathrm{Br}, \mathrm{Br} / \mathrm{I}, \mathrm{I})$ System. Front. Chem. 2020, 8, 1-9.

(28) Tan, Z.; Li, J.; Zhang, C.; Li, Z.; Hu, Q.; Xiao, Z.; Kamiya, T.; Hosono, H.; Niu, G.; Lifshitz, E.; Cheng, Y.; Tang, J. Highly Efficient BlueEmitting Bi-Doped $\mathrm{Cs}_{2} \mathrm{SnCl}_{6}$ Perovskite Variant: Photoluminescence Induced by Impurity Doping. Adv. Funct. Mater. 2018, 28, 1801131.

(29) Jing, Y.; Liu, Y.; Zhao, J.; Xia, Z. Sb ${ }^{3+}$ Doping-Induced Triplet SelfTrapped Excitons Emission in Lead-Free $\mathrm{Cs}_{2} \mathrm{SnCl}_{6}$ Nanocrystals. J. Phys. Chem. Lett. 2019, 10, 7439-7444.

(30) Arfin, H.; Kshirsagar, A. S.; Kaur, J.; Mondal, B.; Xia, Z.; Chakraborty, S.; Nag, A. Ns2 Electron $\left(\mathrm{Bi}^{3+}\right.$ and $\left.\mathrm{Sb}^{3+}\right)$ Doping in Lead-Free Metal Halide Perovskite Derivatives. Chem. Mater 2020, 32, 10255-10267.

(31) Wasylishen, R. E.; Knop, 0.; Macdonald, J. B. Cation Rotation in Methylammonium Lead Halides. Solid State Commun. 1985, 56, 581-582.

(32) Kubicki, D. J.; Prochowicz, D.; Hofstetter, A.; Zakeeruddin, S. M.; Grätzel, M.; Emsley, L. Phase Segregation in Potassium-Doped Lead Halide Perovskites from ${ }^{39} \mathrm{~K}$ Solid-State NMR at $21.1 \mathrm{~T}$. $J$. Am. Chem. Soc. 2018, 140, 7232-7238.

(33) Kubicki, D. J.; Prochowicz, D.; Hofstetter, A.; Péchy, P.; Zakeeruddin, S. M.; Grätzel, M.; Emsley, L. Cation Dynamics in Mixed-Cation $(\mathrm{MA})_{\mathrm{x}}(\mathrm{FA})_{1-\mathrm{x}} \mathrm{PbI}_{3}$ Hybrid Perovskites from SolidState NMR. J. Am. Chem. Soc. 2017, 139, 10055-10061.

(34) Kubicki, D. J.; Prochowicz, D.; Hofstetter, A.; Saski, M.; Yadav, P.; Bi, D.; Pellet, N.; Lewiński, J.; Zakeeruddin, S. M.; Grätzel, M.; Emsley, L. Formation of Stable Mixed GuanidiniumMethylammonium Phases with Exceptionally Long Carrier Lifetimes for High-Efficiency Lead Iodide-Based Perovskite Photovoltaics. J. Am. Chem. Soc. 2018, 140, 3345-3351.

(35) Bernard, G. M.; Wasylishen, R. E.; Ratcliffe, C. I.; Terskikh, V.; Wu, Q.; Buriak, J. M.; Hauger, T. Methylammonium Cation Dynamics in Methylammonium Lead Halide Perovskites: A Solid-State NMR Perspective. J. Phys. Chem. A 2018, 122, 1560-1573.

(36) Karmakar, A.; Dodd, M. S.; Zhang, X.; Oakley, M. S.; Klobukowski, M.; Michaelis, V. K. Mechanochemical Synthesis of OD and 3D Cesium Lead Mixed Halide Perovskites. Chem. Commun. 2019, $55,5079-5082$.

(37) Askar, A. M.; Karmakar, A.; Bernard, G. M.; Ha, M.; Terskikh, V. V.; Wiltshire, B. D.; Patel, S.; Fleet, J.; Shankar, K.; Michaelis, V. K. Composition-Tunable Formamidinium Lead Mixed Halide Perovskites via Solvent-Free Mechanochemical Synthesis: Decoding the $\mathrm{Pb}$ Environments Using Solid-State NMR Spectroscopy. J. Phys. Chem. Lett. 2018, 9, 2671-2677.
(38) Karmakar, A.; Askar, A. M.; Bernard, G. M.; Terskikh, V. V.; Ha, M.; Patel, S.; Shankar, K.; Michaelis, V. K. Mechanochemical Synthesis of Methylammonium Lead Mixed-Halide Perovskites: Unraveling the Solid-Solution Behavior Using Solid-State NMR. Chem. Mater. 2018, 30, 2309-2321.

(39) Kubicki, D. J.; Prochowicz, D.; Hofstetter, A.; Walder, B. J.; Emsley, L. ${ }^{113} \mathrm{Cd}$ Solid-State NMR at $21.1 \mathrm{~T}$ Reveals the Local Structure and Passivation Mechanism of Cadmium in Hybrid and AllInorganic Halide Perovskites. ACS Energy Lett. 2020, 5, 2964-2971.

(40) Rosales, B. A.; Men, L.; Cady, S. D.; Hanrahan, M. P.; Rossini, A. J.; Vela, J. Persistent Dopants and Phase Segregation in Organolead Mixed-Halide Perovskites. Chem. Mater. 2016, 28, 6848-6859.

(41) Rosales, B. A.; Hanrahan, M. P.; Boote, B. W.; Rossini, A. J.; Smith, E. A.; Vela, J. Lead Halide Perovskites: Challenges and Opportunities in Advanced Synthesis and Spectroscopy. ACS Energy Lett. 2017, 2, 906-914.

(42) Chen, Y.; Smock, S. R.; Flintgruber, A. H.; Perras, F. A.; Brutchey, R. L.; Rossini, A. J. Surface Termination of $\mathrm{CsPbBr}_{3}$ Perovskite Quantum Dots Determined by Solid-State NMR Spectroscopy .J. Am. Chem. Soc. 2020, 142, 6117-6127.

(43) Franssen, W. M. J.; Kentgens, A. P. M. Solid-State NMR of Hybrid Halide Perovskites. Solid State Nucl. Magn. Reson. 2019, 100, 3644.

(44) Wouter M. J. Franssen; Es, S. G. D. van; Dervişoğlu, R.; Wijs, G. A. de; Kentgens, A. P. M. Symmetry, Dynamics, and Defects in Methylammonium Lead Halide Perovskites. J. Phys. Chem. Lett. 2017, 8, 61-66.

(45) Senocrate, A.; Moudrakovski, I.; Kim, G. Y.; Yang, T.; Gregori, G.; Grätzel, M.; Maier, J. The Nature of Ion Conduction in Methylammonium Lead Iodide: A Multimethod Approach. Angew. Chem. Int. Ed. 2017, 56, 7755-7759.

(46) Senocrate, A.; Moudrakovski, I.; Acartuerk, T.; Merkle, R.; Kim, G. Y.; Starke, U.; Grätzel, M.; Maier, J. Slow $\mathrm{CH}_{3} \mathrm{NH}_{3}{ }^{+}$Diffusion in $\mathrm{CH}_{3} \mathrm{NH}_{3} \mathrm{PbI}_{3}$ Under Light Measured by Solid-State NMR and Tracer Diffusion. J. Phys. Chem. C 2018, 122, 21803-21806.

(47) Prochowicz, D.; Yadav, P.; Saliba, M.; Kubicki, D. J.; Tavakoli, M. M.; Zakeeruddin, S. M.; Lewiński, J.; Emsley, L.; Grätzel, M. OneStep Mechanochemical Incorporation of an Insoluble Cesium Additive for High Performance Planar Heterojunction Solar Cells Nano Energy 2018, 49, 523-528.

(48) Harris, R. K.; Becker, E. D. NMR Nomenclature: Nuclear Spin Properties and Conventions for Chemical Shifts-IUPAC Recommendations. J. Magn. Reson. 2002, 156, 323-326.

(49) Karmakar, A.; Bernard, G. M.; Meldrum, A.; Oliynyk, A. O.; Michaelis, V. K. Tailorable Indirect to Direct Bandgap Double Perovskites with Bright White-Light Emission: Decoding Chemical Structure Using Solid-State NMR. J. Am. Chem. Soc. 2020, 142, 10780-10793.

(50) Karmakar, A.; Dodd, M. S.; Agnihotri, S.; Ravera, E.; Michaelis, V. K. $\mathrm{Cu}(\mathrm{II})$-Doped $\mathrm{Cs}_{2} \mathrm{SbAgCl}_{6}$ Double Perovskite: A Lead-Free, Low-Bandgap Material. Chem. Mater. 2018, 30, 8280-8290.

(51) Kubicki, D. J.; Prochowicz, D.; Pinon, A.; Stevanato, G.; Hofstetter A.; Zakeeruddin, S. M.; Grätzel, M.; Emsley, L. Doping and Phase Segregation in $\mathrm{Mn}^{2+}$ - and $\mathrm{Co}^{2+}$-Doped Lead Halide Perovskites from ${ }^{133} \mathrm{Cs}$ and ${ }^{1} \mathrm{H}$ NMR Relaxation Enhancement. J. Mater. Chem. A 2019, 7, 2326-2333.

(52) Kubicki, D. J.; Prochowicz, D.; Hofstetter, A.; Zakeeruddin, S. M.; Grätzel, M.; Emsley, L. Phase Segregation in Cs-, Rb- and K-Doped Mixed-Cation (MA) $)_{x}(\mathrm{FA})_{1-\mathrm{x}} \mathrm{PbI}_{3}$ Hybrid Perovskites from SolidState NMR. J. Am. Chem. Soc. 2017, 139, 14173-14180.

(53) Wolf, P.; Valla, M.; Núñez-Zarur, F.; Comas-Vives, A.; Rossini, A. J.; Firth, C.; Kallas, H.; Lesage, A.; Emsley, L.; Copéret, C.; Hermans, I Correlating Synthetic Methods, Morphology, Atomic-Level Structure, and Catalytic Activity of Sn- $\beta$ Catalysts. ACS Catal. 2016, 6, 4047-4063.

(54) Grykałowska, A.; Nowak, B. High-Resolution Solid-State 119Sn and ${ }^{195 P t}$ NMR Studies of MPtSn Semiconductors $(\mathrm{M}=\mathrm{Ti}, \mathrm{Zr}, \mathrm{Hf}$ Th). Solid State Nucl. Magn. Reson. 2005, 27, 223-227.

(55) Wrackmeyer, B. Application of ${ }^{119}$ Sn NMR Parameters. Editor: G. A. Webb, Annu. Rep. NMR Spectrosc., Academic Press, 1999; Vol. 38, pp 203-264. 
(56) Ha, M.; Karmakar, A.; Bernard, G. M.; Basilio, E.; Krishnamurthy, A.; Askar, A. M.; Shankar, K.; Kroeker, S.; Michaelis, V. K. Phase Evolution in Methylammonium Tin Halide Perovskites with Variable Temperature Solid-State ${ }^{119}$ Sn NMR Spectroscopy. J. Phys. Chem. C 2020, 124, 15015-15027.

(57) Jastrzebski, J. T. B. H.; Grove, D. M.; Boersma, J.; van Koten, G.; Ernsting, J. -M. ${ }^{119}$ Sn NMR Study of Organotin Compounds Having Intramolecular Sn-N Coordination. Magn. Reson. Chem. 1991, $29, \mathrm{~S} 25-\mathrm{S} 30$.

(58) Gunther, W. R.; Michaelis, V. K.; Caporini, M. A.; Griffin, R. G.; Román-Leshkov, Y. Dynamic Nuclear Polarization NMR Enables the Analysis of Sn-Beta Zeolite Prepared with Natural Abundance 119Sn Precursors. J. Am. Chem. Soc. 2014, 136, 62196222.

(59) Karmakar, A.; Bhattacharya, A.; Bernard, G. M.; Mar, A.; Michaelis, $\mathrm{V}$. K. Revealing the Local $\mathrm{Sn}$ and $\mathrm{Pb}$ Arrangements in $\mathrm{CsSn}_{\mathrm{x}} \mathrm{Pb}_{1-\mathrm{x}} \mathrm{Br}_{3}$ Perovskites with Solid-State NMR Spectroscopy. ACS Mater. Lett. 2021, 3, 261-267.

(60) Yeh, H. M. M.; Geanangel, R. A. 119Sn NMR Spectra of Tin(II) Halides. Inorganica Chim. Acta 1981, 52, 113-118.

(61) Amornsakchai, P.; Apperley, D. C.; Harris, R. K.; Hodgkinson, P.; Waterfield, P. C. Solid-State NMR Studies of Some Tin(II) Compounds. Solid State Nucl. Magn. Reson. 2004, 26, 160-171.

(62) Hunter, B. K.; Reeves, L. W. Chemical Shifts for Compounds of the Group IV Elements Silicon and Tin. Can. J. Chem. 1968, 46, 13991414.

(63) Shannon, R. D. Revised Effective Ionic Radii and Systematic Studies of Interatomie Distances in Halides and Chaleogenides. Acta Cryst. 1976, A32, 751-767.

(64) Kaltzoglou, A.; Antoniadou, M.; Kontos, A. G.; Stoumpos, C. C.; Perganti, D.; Siranidi, E.; Raptis, V.; Trohidou, K.; Psycharis, V.; Kanatzidis, M. G.; Falaras, P. Optical-Vibrational Properties of the $\mathrm{Cs}_{2} \mathrm{SnX}_{6}(\mathrm{X}=\mathrm{Cl}, \mathrm{Br}, \mathrm{I})$ Defect Perovskites and Hole-Transport Efficiency in Dye-Sensitized Solar Cells. J. Phys. Chem. C 2016 , 120, 11777-11785.

(65) Xiao, Z.; Zhou, Y.; Hosono, H.; Kamiya, T. Intrinsic Defects in a Photovoltaic Perovskite Variant $\mathrm{Cs}_{2} \mathrm{SnI}_{6}$. Phys. Chem. Chem. Phys. 2015, 17, 18900-18903.

(66) Dmitrenko, O.; Bai, S.; Dybowski, C. Prediction of ${ }^{207} \mathrm{~Pb}$ NMR Parameters for the Solid Ionic Lead(II) Halides Using the Relativistic ZORA-DFT Formalism: Comparison with the LeadContaining Molecular Systems. Solid State Nucl. Magn. Reson 2008, 34, 186-190.

(67) Aebli, M.; Piveteau, L.; Nazarenko, O.; Benin, B. M.; Krieg, F.; Verel, R.; Kovalenko, M. V. Lead-Halide Scalar Couplings in ${ }^{207} \mathrm{~Pb}$ NMR of $\mathrm{APbX}_{3}$ Perovskites $(\mathrm{A}=\mathrm{Cs}$, Methylammonium, Formamidinium; X = Cl, Br, I). Sci. Rep. 2020, 10, 8229.

(68) Sharp, R. R. Rotational Diffusion and Magnetic Relaxation of ${ }^{119} \mathrm{Sn}$ in Liquid $\mathrm{SnCl}_{4}$ and $\mathrm{SnI}_{4}$. J. Chem. Phys. 1972, 57, 53215330.

(69) Sharp, R. R. Field Dependence of Nuclear Magnetic Relaxation of ${ }^{119} \mathrm{Sn}$ in $\mathrm{SnCl}_{4}, \mathrm{SnBr}_{4}$, and $\mathrm{Snl}_{4}$. J. Chem. Phys. 1974, 60, 11491157.

(70) Hamaed, H.; Pawlowski, J. M.; Cooper, B. F. T.; Fu, R.; Eichhorn, S H.; Schurko, R. W. Application of Solid-State ${ }^{35} \mathrm{Cl}$ NMR to the Structural Characterization of Hydrochloride Pharmaceuticals and Their Polymorphs. J. Am. Chem. Soc. 2008, 130, 1105611065.

(71) Widdifield, C. M.; Chapman, R. P.; Bryce, D. L. Chlorine, Bromine, and Iodine Solid-State NMR Spectroscopy, 1st ed.; Elsevier Ltd., 2009; Vol. 66.

(72) Chapman, R. P.; Widdifield, C. M.; Bryce, D. L. Solid-State NMR of Quadrupolar Halogen Nuclei. Prog. Nucl. Magn. Reson. Spectrosc. 2009, 55, 215-237.

(73) Piveteau, L.; Aebli, M.; Yazdani, N.; Millen, M.; Korosec, L.; Krieg, F.; Benin, B. M.; Morad, V.; Piveteau, C.; Shiroka, T.; Comas-Vives, A.; Copéret, C.; Lindenberg, A. M.; Wood, V.; Verel, R.; Kovalenko, M. V. Bulk and Nanocrystalline Cesium Lead-Halide Perovskites as Seen by Halide Magnetic Resonance. ACS Cent. Sci. 2020, 6 , 1138-1149.

(74) Greer, B. J.; Michaelis, V. K.; Terskikh, V. V; Kroeker, S. Reconnaissance of Diverse Structural and Electronic
Environments in Germanium Halides by Solid-State ${ }^{73} \mathrm{Ge}$ NMR and Quantum Chemical Calculations. Can. J. Chem. 2011, 89, 1118-1129.

(75) Lucier, B. E. G.; Terskikh, V. V; Guo, J.; Bourque, J. L.; Mconie, S. L.; Ripmeester, J. A.; Huang, Y.; Baines, K. M. Chlorine-35 Solid-State Nuclear Magnetic Resonance Spectroscopy as an Indirect Probe of the Oxidation Number of Tin in Tin Chlorides. Inorg. Chem. 2020, 59, 13651-13670.

(76) O’Dell, L. A.; Schurko, R. W. QCPMG Using Adiabatic Pulses for Faster Acquisition of Ultra-Wideline NMR Spectra. Chem. Phys. Lett. 2008, 464, 97-102.

(77) Dell, L. A. O. The WURST Kind of Pulses in Solid-State NMR. Solid State Nucl. Magn. Reson. 2013, 55-56, 28-41.

(78) Patrick, C. E.; Jacobsen, K. W.; Thygesen, K. S. Anharmonic Stabilization and Band Gap Renormalization in the Perovskite CsSnI 3. Phys. Rev. B 2015, 92, 201205.

(79) Yaffe, O.; Guo, Y.; Tan, L. Z.; Egger, D. A.; Hull, T.; Stoumpos, C. C.; Zheng, F.; Heinz, T. F.; Kronik, L.; Kanatzidis, M. G.; Owen, J. S.; Rappe, A. M.; Pimenta, M. A.; Brus, L. E. Local Polar Fluctuations in Lead Halide Perovskite Crystals. Phys. Rev. Lett. 2017, 118, 136001.

(80) Yang, R. X.; Skelton, J. M.; Da Silva, E. L.; Frost, J. M.; Walsh, A. Spontaneous Octahedral Tilting in the Cubic Inorganic Cesium Halide Perovskites $\mathrm{CsSnX}_{3}$ and $\mathrm{CsPbX}_{3}(\mathrm{X}=\mathrm{F}, \mathrm{Cl}, \mathrm{Br}, \mathrm{I})$. J. Phys. Chem. Lett. 2017, 8, 4720-4726.

(81) Maughan, A. E.; Ganose, A. M.; Candia, A. M.; Granger, J. T.; Scanlon, D. O.; Neilson, J. R. Anharmonicity and Octahedral Tilting in Hybrid Vacancy-Ordered Double Perovskites. Chem. Mater. 2018, 30, 472-483.

(82) Maughan, A. E.; Paecklar, A. A.; Neilson, J. R. Bond Valences and Anharmonicity in Vacancy-Ordered Double Perovskite Halides. J. Mater. Chem. C 2018, 6, 12095-12104.

(83) Dunlap-Shohl, W. A.; Zhou, Y.; Padture, N. P.; Mitzi, D. B. Synthetic Approaches for Halide Perovskite Thin Films. Chem. Rev. 2019 119, 3193-3295.

(84) Liu, M.; Johnston, M. B.; Snaith, H. J. Efficient Planar Heterojunction Perovskite Solar Cells by Vapour Deposition. Nature 2013, 501, 395-398.

(85) James, S. L.; Adams, C. J.; Bolm, C.; Braga, D.; Collier, P.; Friscic, T.; Grepioni, F.; Harris, K. D. M.; Hyett, G.; Jones, W.; Krebs, A.; Mack J.; Maini, L.; Orpen, A. G.; Parkin, I. P.; Shearouse, W. C.; Steed, J. W.; Waddell, D. C. Mechanochemistry: Opportunities for New and Cleaner Synthesis. Chem. Soc. Rev. 2012, 41, 413-447.

(86) Chizhik, S.; Panda, M. K.; Nath, N. K.; Boldyreva, E. Mechanically Responsive Molecular Crystals. Chem. Rev. 2015, 115, 12440-12490.

(87) Stock, N.; Biswas, S. Synthesis of Metal-Organic Frameworks (MOFs): Routes to Various MOF Topologies, Morphologies, and Composites. Chem. Rev. 2012, 112, 933-969.

(88) Prochowicz, D.; Franckevicius, M.; Cieslak, A. M.; Zakeeruddin, S. M.; Graatzel, M.; Lewinski, J. Mechanosynthesis of the Hybrid Perovskite $\mathrm{CH}_{3} \mathrm{NH}_{3} \mathrm{PbI}_{3}$ : Characterization and the Corresponding Solar Cell Efficiency. J. Mater. Chem. A 2015, 3, 20772-20777.

(89) Rosales, B. A.; Wei, L.; Vela, J. Synthesis and Mixing of Complex Halide Perovskites by Solvent-Free Solid-State Methods. J. Solid State Chem. 2019, 271, 206-215.

(90) Hong, Z.; Tan, D.; John, R. A.; Tay, Y. K. E.; Ho, Y. K. T.; Zhao, X.; Sum, T. C.; Mathews, N.; García, F.; Soo, H. Sen. Completely Solvent-Free Protocols to Access Phase-Pure, Metastable Metal Halide Perovskites and Functional Photodetectors from the Precursor Salts. iScience 2019, 16, 312-325.

(91) Protesescu, L.; Yakunin, S.; Nazarenko, O.; Dirin, D. N.; Kovalenko, M. V. Low-Cost Synthesis of Highly Luminescent Colloidal Lead Halide Perovskite Nanocrystals by Wet Ball Milling. ACS Appl. Nano Mater. 2018, 1, 1300-1308.

(92) Prochowicz, D.; Franckevičius, M.; Cies̈lak, A. M.; Zakeeruddin, S. M.; Grätzel, M.; Lewiński, J. Mechanosynthesis of the Hybrid Perovskite $\mathrm{CH}_{3} \mathrm{NH}_{3} \mathrm{PbI}_{3}$ : Characterization and the Corresponding Solar Cell Efficiency. J. Mater. Chem. A 2015, 3, $20772-20777$.

(93) Zarick, H. F.; Soetan, N.; Erwin, W. R.; Bardhan, R. Mixed Halide Hybrid Perovskites: A Paradigm Shift in Photovoltaics. J. Mater Chem. A 2018, 6, 5507-5537. 
(94) Karim, M. M. S.; Ganose, A. M.; Pieters, L.; Winnie Leung, W. W.; Wade, J.; Zhang, L.; Scanlon, D. O.; Palgrave, R. G. Anion Distribution, Structural Distortion, and Symmetry-Driven Optical Band Gap Bowing in Mixed Halide $\mathrm{Cs}_{2} \mathrm{SnX}_{6}$ Vacancy Ordered Double Perovskites. Chem. Mater. 2019, 31, 9430-9444.

(95) Im, J.; Stoumpos, C. C.; Jin, H.; Freeman, A. J.; Kanatzidis, M. G. Antagonism between Spin-Orbit Coupling and Steric Effects
Causes Anomalous Band Gap Evolution in the Perovskite Photovoltaic Materials $\mathrm{CH}_{3} \mathrm{NH}_{3} \mathrm{Sn}_{1-\mathrm{x}} \mathrm{Pb}_{\mathrm{x}} \mathrm{I}_{3}$. J. Phys. Chem. Lett. 2015, 6, 3503-3509.

\section{TOC graphic}

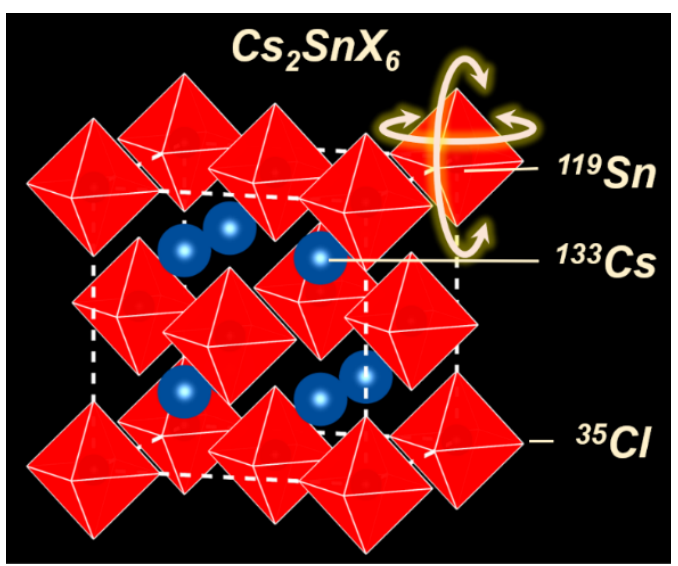

